\title{
Developmental origins of brain disorders: roles for dopamine
}

\author{
Kelli M. Money ${ }^{1,2}$ and Gregg D. Stanwood ${ }^{3,4} *$ \\ ${ }^{1}$ Neuroscience Graduate Program, Vanderbilt University, Nashville, TN, USA \\ ${ }^{2}$ Vanderbilt Medical Scientist Training Program, Vanderbilt University, Nashville, TN, USA \\ ${ }^{3}$ Department of Pharmacology, Vanderbilt University, Nashville, TN, USA \\ ${ }^{4}$ Vanderbilt Kennedy Center for Research on Human Development, Vanderbilt University, Nashville, TN, USA
}

\author{
Edited by: \\ Yehezkel Ben-Ari, Institut National de \\ la Santé et de la Recherche Médicale, \\ France

\section{Reviewed by:} \\ James M. Tepper, Rutgers, The State \\ University of New Jersey, USA \\ Evelyne Sernagor, Newcastle \\ University, UK \\ *Correspondence: \\ Gregg D. Stanwood, Department of \\ Pharmacology, Vanderbilt University, \\ 23rd Avenue South, 476 Robinson \\ Research Building, Nashville, TN \\ 37232-6600, USA \\ e-mail: gregg.stanwood@ \\ vanderbilt.edu
}

Neurotransmitters and neuromodulators, such as dopamine, participate in a wide range of behavioral and cognitive functions in the adult brain, including movement, cognition, and reward. Dopamine-mediated signaling plays a fundamental neurodevelopmental role in forebrain differentiation and circuit formation. These developmental effects, such as modulation of neuronal migration and dendritic growth, occur before synaptogenesis and demonstrate novel roles for dopaminergic signaling beyond neuromodulation at the synapse. Pharmacologic and genetic disruptions demonstrate that these effects are brain region- and receptor subtype-specific. For example, the striatum and frontal cortex exhibit abnormal neuronal structure and function following prenatal disruption of dopamine receptor signaling. Alterations in these processes are implicated in the pathophysiology of neuropsychiatric disorders, and emerging studies of neurodevelopmental disruptions may shed light on the pathophysiology of abnormal neuronal circuitry in neuropsychiatric disorders.

Keywords: neurodevelopment, frontal cortex, striatum, D1 receptor, D2 receptor, neuropsychiatric disease, dendrite, migration

\section{INTRODUCTION}

Brain development requires a complex interplay of genetic and environmental factors. Disruption of these elements can affect neuronal structure, function, or connectivity and can alter developmental trajectory. In turn, this can lead to long-lasting, even permanent, effects and contribute to brain disorders later in life (Finlay, 2001; Lewis and Levitt, 2002; Frederick and Stanwood, 2009; Thompson etal., 2009; Rapoport et al., 2012; Ben-Ari, 2013). Neurodevelopmental alterations in the frontal/prefrontal cortex and striatum, which are both heavily involved in cognition, memory, emotion, and learning, are likely involved in the etiology of neuropsychiatric disorders like autism, substance use disorders, and schizophrenia (Simpson etal., 2010; Langen et al., 2012; Jonas et al., 2013). These brain regions receive prominent dopamine (DA) innervations and express DA receptors (Bjorklund and Dunnett, 2007; Tritsch and Sabatini, 2012; Roeper, 2013). In fact, DA and other neurotransmitters are expressed even prior to synaptogenesis, and activation of their receptors during development alters brain structure and connectivity with enduring anatomical and behavioral effects through adulthood (Schmidt et al., 1996; Spencer et al., 1998; Stanwood and Levitt, 2001, 2007; Stanwood et al., 2005; Bhide, 2009; Lu et al., 2009; Zhang et al., 2010; Bellone et al., 2011; Hamilton et al., 2011; McCarthy et al., 2011). However, the cellular and functional consequences of these activities are still poorly understood, and their linkages to specific diseases are often indirect and poorly elucidated.

Here we will review evidence for the role of DA receptors in neurodevelopmental processes with an emphasis on how DA D1 and D2 receptors modulate neuronal morphology in the frontal cortex and striatum. We will then briefly discuss the relevant intracellular signaling mechanisms through which DA receptors modulate neuronal morphology, and conclude with the implications of altered DA signaling on our understanding of the etiology and pathophysiology of neuropsychiatric disorders.

\section{ONTOGENY OF DOPAMINERGIC INNERVATION AND RECEPTOR EXPRESSION PATTERNS}

DA innervation and receptor expression are present early in development, mature during adolescence, and form stable patterns in young adulthood. This prolonged developmental timeline provides a large window of "critical periods" during which potential disruptors can induce varied effects. For example, a landmark study by Andersen et al. (2002) showed that repeated exposure to methylphenidate (Ritalin) during the juvenile period reduces cocaine reward in adulthood, whereas adult methylphenidate exposure does not confer this protection.

Alterations in DA innervation patterns and receptor expression have been found in several brain disorders, including psychiatric disease. A decrease in DAergic axons in deep layers of medial prefrontal cortex and decreased D1 receptor binding occurs in schizophrenic patients (Okubo et al., 1997; Akil et al., 1999). In addition, increased $\mathrm{D} 2$ receptor binding in the striatum has been observed in patients with ADHD and depression (D'Haenen and Bossuyt, 1994; Shah et al., 1997). An understanding of the developmental timeline of the DA system and points at which the normal developmental trajectory can be altered are crucial to explore the implications of DAergic disruption. 
The frontal cortex and striatum are innervated by DAcontaining axons from the mesencephalic DA nuclei by mid-to-late gestation in rodents (Verney etal., 1982; Kalsbeek et al., 1988; Voorn et al., 1988), the predominant animal models used to study the developmental roles of DA. Voorn et al. (1988) demonstrated that DA innervation develops in well-defined spatiotemporal gradients in the lateral ganglionic eminence (presumptive striatum) that begins by embryonic day (E) 14 and coincides with striatal neurogenesis and cell differentiation. The rat developing cortex receives DAergic fibers that pass through the striatum, with innervation occurring in a lateral (E16) to medial fashion (E19). At birth, DAergic fibers are concentrated in the developing layer VI of frontal cortex. Fiber density increases over time in the deep layers of cortex with some fibers innervating more superficial layers in discrete cortical regions as the more superficial cortical layers develop (Kalsbeek et al., 1988). Mature DAergic innervation patterns are established in both regions by postnatal day 60 . Studies in other species suggest that these sequences of events are very well conserved evolutionarily, although the exact timings are of course quite different based on gestation length (see below).

Dopamine receptor expression develops in concert with DAergic innervation. DA receptors are part of the G-protein coupled receptor superfamily and can be classified into two subgroups based on sequence, pharmacology, and G protein signaling: D1like, which includes D1 and D5 receptors, and D2-like, which includes D2, D3, and D4 receptors (Missale et al., 1998; Beaulieu and Gainetdinov, 2011). Even before DAergic afferents have fully occupied the striatum or cortex, the main two DA receptor subtypes (D1 and D2 receptors) are already present (Schambra et al., 1994; Araki et al., 2007; Sillivan and Konradi, 2011). Higher levels of expression for both subtypes are found in the striatum compared to frontal cortex from development to adulthood (Araki et al., 2007; Sillivan and Konradi, 2011), and the D1 receptor subtype is expressed at higher levels than the D2 receptor subtype in both regions (Boyson et al., 1986; Neisewander et al., 1991; Couppis et al., 2008). D3, D4, and D5 receptors are consistently expressed at lower levels but still are present even during prenatal development. For example, D3 and D5 receptor mRNA is first found in the striatum at E12 and frontal cortex by E15 (Araki et al., 2007). However, D4 receptor mRNA, which is also present in the striatum at E12 and frontal cortex by E15, has its highest expression during embryonic development (Araki et al., 2007). D4 receptor mRNA decreases after birth with a more significant drop in expression seen in the frontal cortex (Nair and Mishra, 1995). D3 receptors are also are expressed transiently within the early postnatal somatosensory cortex during a key critical period of plasticity (Gurevich and Joyce, 2000; Gurevich etal., 2001), although their function there remains unknown.

Dopaminergic development continues postnatally and impacts forebrain synaptogenesis and connectivity. For example, D1 receptor pruning is specifically associated with maturation of the excitation-inhibition balance in frontal cortex during adolescence (Andersen et al., 2000). Jung and Bennett (1996) demonstrated that D1 receptor expression steadily declines after the fourth postnatal week, which has been confirmed by others and is illustrated in Figure 1C (Andersen et al., 2000; Araki et al., 2007; Brenhouse et al., 2008). Cortical circuits and processing relies on connectivity and excitability of both excitatory glutamatergic pyramidal neurons and inhibitory GABAergic interneurons. Disruptions of excitation-inhibition balance in the frontal cortex have been reported in patients with schizophrenia, autism, major depressive disorder, and obsessive compulsive disorder (Harada et al., 2011; Cornew etal., 2012; Radhu etal., 2013), and many of these patients present with a first episode around adolescence. Risk of substance abuse disorders also increases during adolescence (O'Brien and Anthony, 2005). Genetically mediated DA variability has been suggested to shape complex behaviors emerging in adolescence, such as impulsivity and sensation seeking (Padmanabhan and Luna, 2013). DAergic regulation of frontal cortex output to subcortical areas mediates drug seeking behavior, with D1 receptor activation enhancing cortically driven drug seeking (Piazza et al., 1991; Kalivas et al., 2005). Moreover, cortical output neurons to the nucleus accumbens, a subcortical reward area, express higher levels of D1 receptors during adolescence in rodent models. This correlates with increased sensitivity to cocaine conditioned place preference. Brenhouse et al. (2008) found this increased preference to be enhanced with microinjections of D1-like receptor agonist in the prefrontal cortex but blunted with D1-like receptor antagonist, demonstrating the importance of D1 receptor signaling in heightened adolescent sensitivity to cocaine preference. This work demonstrates how the prolonged development of the DA system allows for vulnerability into adolescence. Thus, inappropriate alterations in D1 receptor signaling during adolescent cortical maturation could play a significant role in the development of neuropsychiatric diseases.

Phylogenetic differences in brain development exist between rodents and higher mammals (Workman et al., 2013). In regards to DA, monkeys and humans have more widespread cortical DA input than rodents and significantly denser DAergic innervation in motor, premotor, and supplementary motor association cortices (Berger etal., 1988, 1991; Gaspar et al., 1989; MeadorWoodruff et al., 1996). Human DAergic innervation occurs early in development and is strongly established by mid-gestation (Olson et al., 1973; Verney et al., 1991, 1993; Zecevic and Verney, 1995). The density of DAergic fibers to the prefrontal cortex in nonhuman primates increases during preadolescence, peaks during adolescence, and then declines (Rosenberg and Lewis, 1995). This evolution of the cortical DAergic system in primates suggests a more substantial role for DAergic innervation in development in more evolved species. The increased influence of DA in the human brain is exemplified by the increase in neuropsychiatric disease onset during adolescence, the time period when the DA system matures. The role of DA system development in neuropsychiatric disease vulnerability is an active area of research, and hopefully, the field will soon understand how to correct aberrant DA development in these vulnerable individuals.

\section{STRIATAL AND CORTICAL DOPAMINERGIC PATHWAYS}

The striatum receives DAergic innervation from the substantia nigra pars compacta, which is known as the nigrostriatal pathway (shown in Figure 2). These DAergic afferents synapse on 
A

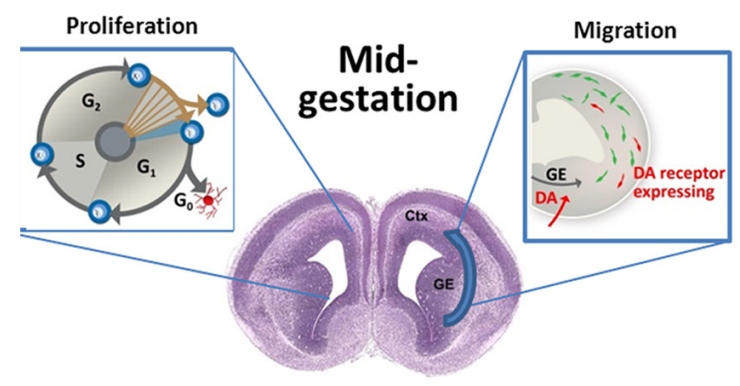

C

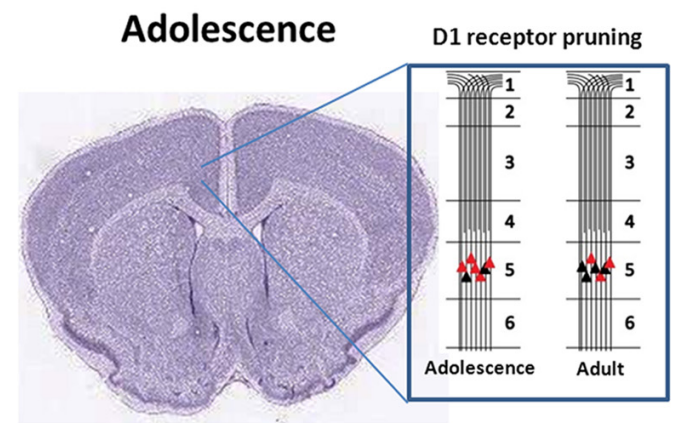

B

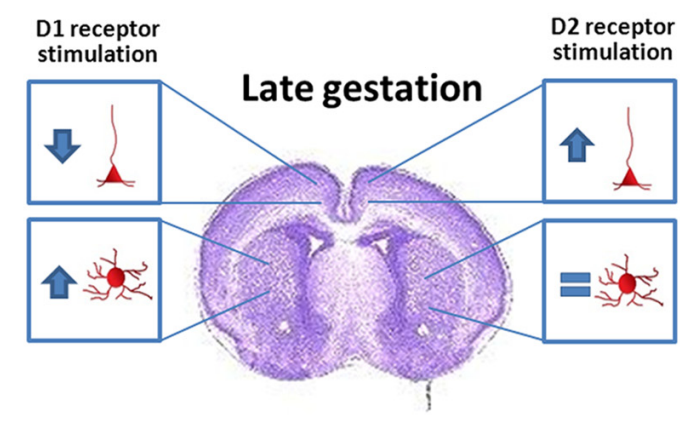

D

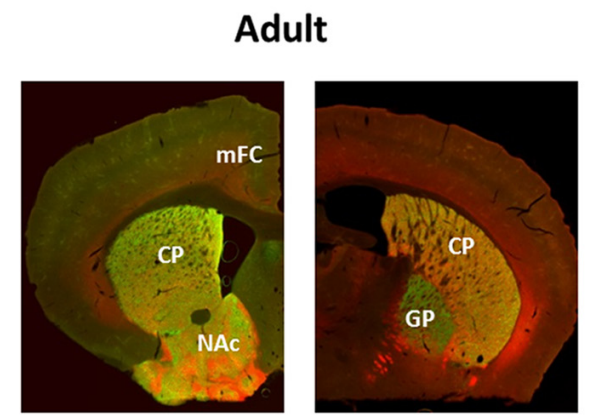

FIGURE 1 | (A) During midgestation DA receptors have subtype-specific effects both on neuronal proliferation and interneuron migration; (B) During late-gestation DA receptors continue to be bioactive and regulate dendritic complexity of both cortical pyramidal neurons and striatal medium spiny projection neurons in a subtype-specific manner; (C) DA receptor expression typically peaks during adolescence and then declines. For D1 receptors in the frontal cortex, this is not just a reduction in total receptors per neuron, but rather a "pruning" of a subpopulation of D1 receptors that are transiently expressed on the terminals of cortico-accumbens neurons (Andersen etal. 2000; Brenhouse etal., 2008); (D) Photomicrographs demonstrate the localization of D1 [red, Drd1-tdTomato reporter (Ade et al., 2011)] and D2
[Drd2-eGFP reporter (Gong etal., 2003)] receptors in the rostral (left) and caudal (right) striatum of the adult mouse. Note the heavy labeling of D1 and D2 expressing cells within the CPu and NAc (note very few of these neurons co-express both receptors). More caudally (right) eGFP-labeled terminals can be visualized within the GP, representing the D2+ indirect pathway. D1+ axons, in contrast, bundle ventromedially to the GP and will eventually terminate in the substantia nigra and ventral tegmental area. $\mathrm{CPu}$,

caudate-putamen; Ctx, cortex; GE, ganglionic eminences; GP, globus pallidus, $\mathrm{mFC}$, medial frontal cortex, and NAc, nucleus accumbens. The brain images in panels $\mathbf{( B )}$ and $\mathbf{( C )}$ are courtesy of the Allen Developing Mouse Brain Atlas and are available from: http://developingmouse.brain-map.org. two distinct populations of GABAergic projection neurons, which express either D1 or D2 receptors (demonstrated in Figure 1D; Shuen et al., 2008; Santana et al., 2009; Ade et al., 2011). These populations send projections directly to or indirectly through the globus pallidus (external globus pallidus in primates) to the substantia nigra pars reticulata and endopeduncular nucleus (internal globus pallidus in primates) to make up the direct (D1 receptor expressing neurons) and indirect (D2 receptor expressing neurons) pathways to modulate movement and goal-oriented behavior (Missale et al., 1998; Beaulieu and Gainetdinov, 2011). Dysfunction within these pathways is a hallmark feature of multiple movement disorders, such as Parkinsonism and Huntingdon's disease. Medications that target DA receptors can also modulate these pathways. For example, typical antipsychotics modulate this system by blocking D2 receptors; this action treats positive symptoms but can also lead to tardive dyskinesia, a serious side effect characterized by involuntary, repetitive movements. The importance of the nigrostriatal DAergic projections onto the direct and indirect pathway projection neurons is made evident by the devastating symptoms that result from disruption of this pathway, but other DAergic pathways can also play an important role in disease.
The ventral tegmental area (VTA), another mesencephalic nucleus, gives rise to two additional DAergic pathways. Projections from the VTA to limbic areas, such as the nucleus accumbens, and to the frontal cortex form the mesolimbic and mesocortical pathways (shown in Figure 2), respectively. In the nucleus accumbens, patterns of D1 and D2 receptor expression are similar to the dorsal striatum (demonstrated in Figure 1D). In addition, the shell of the nucleus accumbens expresses high levels of D3 receptors (Le Moine and Bloch, 1995). DA receptor expression is lower in the frontal cortex and found in several types of neurons. In the frontal cortex, D1 receptors appear to be the most prominent $\mathrm{DA}$ receptor, and both D1 and D2 receptors are found in deep layer V/VI glutamatergic projection neurons and parvalbumincontaining GABAergic interneurons (Le Moine and Gaspar, 1998; Muly et al., 1998). D4 and D5 receptors are expressed at low levels in frontal cortex (Beaulieu and Gainetdinov, 2011). Importantly, these pathways and DA receptor expression patterns have great functional significance. The mesolimbic pathway is mainly associated with reward, while the mesocortical pathway is associated with cognitive function. Aberrant reward processing drives substance abuse disorders, and cognitive dysfunction exists as an often 


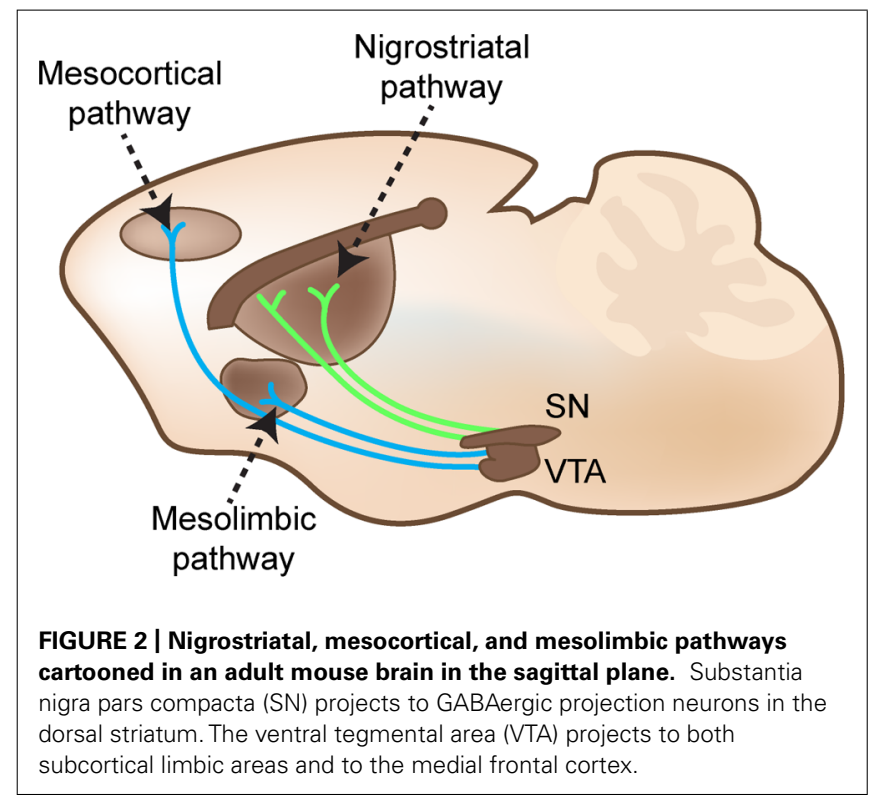

overlooked but devastating feature of many neuropsychiatric disorders (Carter et al., 1998; Bosboom et al., 2004; Medalia and Lim, 2004). Studies of imbalanced mesolimbic and mesocortical DAergic signaling support a potential therapeutic role for DA in reward and cognitive dysfunction in neuropsychiatric disease (Murphy et al., 1996; Volkow et al., 1998; Goldman-Rakic et al., 2004). Thus, DA can influence multiple aspects of human behavior both directly through striatal projections and indirectly through alterations in reward and cognition (for description of the trajectories of growing DA axons and signals contributing to topography, see Prestoz et al., 2012).

\section{DEVELOPMENTAL EFFECTS OF DOPAMINERGIC MODULATION}

DA is one of the earliest neurotransmitters expressed in the developing brain and plays a significant role in the development of neuronal cytoarchitecture. The presence of DAergic projections to the developing cortex and striatum, as well as DA receptors on precursor cells, places DA in an ideal position to modulate neuronal development, including cell proliferation, migration, and differentiation all of which can lead to altered connectivity and dysfunctional synapses. In fact, genetic and pharmacologic models of disrupted DA signaling display changes in cortical and striatal circuitry (Stanwood et al., 2001b, 2005; Song et al., 2002; Kellendonk et al., 2006; McCarthy et al., 2007; Zhang et al., 2010). Environmental, social, and inflammatory challenges during sensitive periods of forebrain development also produce neuro(mal)adaptions in these regions and phenocopy some aspects of brain disorders (Di Forti et al., 2007; Kern et al., 2010; Han et al., 2012; Selemon and Friedman, 2013). For example, models of prenatal infection, stress, and exposure to drugs of abuse show long-lasting changes in DA receptor expression and function and have been associated with increased risk for psychiatric disorders (Alonso et al., 1994; Stanwood et al., 2001b; Berger et al., 2002; Zuckerman et al., 2003; Andersen and Teicher, 2009; Bhide, 2009; Brown et al., 2012). Taken together, these data have led our group and others to hypothesize that DAergic modulation of developmental processes produces long lasting alterations that contribute to cortical and striatal dysfunction in neuropsychiatric disorders.

\section{NEUROPROGENITOR PROLIFERATION}

The earliest observed developmental effects of altered DA signaling are changes in neuroprogenitor proliferation. Selective D1-like receptor agonists can decrease incorporation of the cell cycle marker bromodeoxyuridine (BrdU) in the developing medial frontal cortex and lateral ganglionic eminence, a basal forebrain progenitor pool that is the source for most striatal neurons (illustrated in Figure 1A). Decreased BrdU incorporation is indicative of less neuronal progenitors undergoing division. Both D1-like and D2-like receptors contribute to neurogenesis but with opposite effects; blockade of D1-like receptors and activation of D2-like receptors increase the number of neuronal progenitors undergoing cell division (Ohtani et al., 2003; Popolo et al., 2004). Administration of the DA precursor L-DOPA during early gestation decreases cell proliferation (McCarthy et al., 2007), suggesting that D1 receptor mediated effects may dominate in vivo. Although these studies did not mechanistically investigate how D1 and D2 receptors alter BrdU incorporation, another group examined receptor-induced changes in cell cycle protein expression. Indeed, D1-like receptor activation promotes downregulation of cyclin D and upregulation of the cyclin dependent kinase inhibitor p27Kip1 (Zhang et al., 2005). Cyclin D promotes the transition from the growth phase to S-phase of the cell cycle while p27Kip1 inhibits it (Sheaff and Roberts, 1998). In addition, Raf-1, a component of the mitogen-activated protein kinase (MAPK) pathway that promotes mitosis, is downregulated by D1like receptor activation (Denhardt, 1999; Zhang et al., 2005). The mechanism by which these effects on cell cycle proteins occur is not known, although it appears to be PKA-independent (Zhang et al., 2005). The effects of transient differences in cell cycle proteins have yet to be understood, but small deviations in the number of cells available to release or receive important developmental signals could significantly alter developmental trajectory. And although it is beyond the scope of our current review, it is also worth noting that both acute and chronic DA depletion decreases subependymal neuronal proliferation (Lewis et al., 1977; Patel et al., 1977), and DA receptors, especially D3 receptors, can guide adult neurogenesis as well (Kim et al., 2010; Egeland et al., 2012; Lao et al., 2013).

\section{MIGRATION}

As mentioned above, inappropriate excitation-inhibition balance in frontal cortex is found in several neuropsychiatric diseases (Harada et al., 2011; Cornew et al., 2012; Radhu et al., 2013), which could be partly due to a lack of adequate interneuron migration. The two main cell types in the frontal cortex, glutamatergic pyramidal projection neurons and GABAergic interneurons, are derived from two separate progenitor pools in the developing rodent forebrain. Pyramidal neurons are produced locally in the neuroepithelium of the developing cortex and migrate radially to the appropriate cortical layer. Concurrently, GABAergic interneurons generated in the basal forebrain in the medial and 
caudal ganglionic eminences migrate tangentially to the cortex (de Carlos et al., 1996; Wonders and Anderson, 2006). The number of GABAergic interneurons increases through mammalian brain evolution beyond what the ganglionic eminences can provide. Therefore, in primates, GABAergic interneurons are also produced in the dorsal forebrain and migrate radially through cortex (Letinic et al., 2002; Petanjek et al., 2009). However, this tangentially migrating population of interneurons is still a substantial portion of interneurons produced, and dysregulation of either population would contribute to neuropsychiatric disease (Hansen et al., 2013; Ma et al., 2013).

GABAergic neurons in the medial and caudal ganglionic eminences express DA receptors, and these forebrain regions receive DAergic innervation during the embryonic period when migration occurs. The Bhide lab has demonstrated that altering DA receptor signaling with prenatal cocaine or receptor-specific agonists/antagonists disrupts tangential migration (illustrated in Figure 1A). Prenatal cocaine exposure decreases tangential migration of cortical GABAergic neurons, perhaps mediated by the loss of D1 receptor signaling (Jones et al., 2000; Crandall et al., 2004; Stanwood and Levitt, 2007; McCarthy et al., 2011). In addition, application of D1-like receptor agonists in mouse embryonic slice cultures promotes cortical GABAergic neuron migration whereas D2-like receptor agonism decreases migration (Crandall et al., 2007). Overexpression of the D1 receptor by in vitro electroporation increases the effect of D1-like receptor agonists on promoting tangential migration (Crandall et al., 2007). The basis for opposing D1 vs. D2 receptor effects is not fully understood, but cytoskeletal reorganization must occur for neuronal migration. D1-like receptor stimulation leads to increased neurite localization of cytoskeletal elements needed for cell motility, such as cytoplasmic dynein motor protein and tubulin, whereas D2-like receptor stimulation leads to increased cell body localization of these cytoskeletal elements. Crandall et al. (2007) suggest that this subtype-specific redistribution of cytoskeletal elements needed for cell motility leads to opposite effects on neuronal migration. Elucidation of the molecular pathways responsible for receptor-dependent modulation of neuronal migration may provide new targets for the restoration of neurodevelopmental trajectory.

\section{DENDRITIC AND AXONAL GROWTH}

Dendritic and axonal growth are activity-dependent, highly dynamic processes that remain partially plastic until adulthood (McAllister, 2000). Disruption of dendritic or axonal growth alters both the quantity and nature of neural connections. Not surprisingly, anomalies in brain connectivity have been linked to several neuropsychiatric diseases, including intellectual disability and schizophrenia (Kaufmann and Moser, 2000; Black et al., 2004). In fact, DA receptor activation modulates dendritic structure, creating subtle but significant changes in brain architecture that may increase vulnerability to neurological and/or neuropsychiatric disease.

In this regard, activation of DA receptors influences axonal and dendritic growth in a subtype-specific manner. Primary cultures have been the primary model to test the in vitro effects of DAergic modulation on neurite outgrowth, a term to describe both the developing axon and dendrite. Several groups demonstrated that D1-like receptor agonists significantly reduce neurite outgrowth in frontal cortical neuronal cultures (Reinoso etal., 1996; Song etal., 2002; Li et al., 2013), which is depicted in Figure 1B. Song et al. (2002) further observed that decreased neurite outgrowth is associated with destabilization of dendritic microtubule associated protein (MAP2) by increased phosphorylation. Increased MAP2 phosphorylation is commonly associated with decreased neurite outgrowth (Sanchez et al., 2000). However, activation of numerous kinases causes MAP2 phosphorylation, providing an effector but not the mechanism (Sanchez et al., 2000). An animal model of prenatal cocaine exposure also demonstrates the importance of cortical D1 receptor signaling to suppress neurite outgrowth. This model produces a long-lasting uncoupling of D1 receptor signaling and concomitant increase in neurite outgrowth (Jones et al., 2000; Stanwood and Levitt, 2007). Our group has also observed increased basal neurite outgrowth in cortical cultures derived from D1 receptor null embryos as compared to cultures derived from wild-type littermates (unpublished data). With regards to axonal effects, evidence suggests that D1-like receptor stimulation also alters cortical axon growth patterns by decreasing expression of the netrin-1 receptor (Sillivan, 2011). In contrast to the growth-suppressing effects of D1-like receptor stimulation, D2-like receptor activation in primary cortical cultures leads to an increase in neurite outgrowth (illustrated in Figure 1B; Todd, 1992; Reinoso et al., 1996). Thus, D1-like receptor stimulation decreases neurite outgrowth and netrin-1 receptor expression whereas D2-like receptor stimulation increases neurite outgrowth in vitro. Yet, the DA receptor-expressing population is only approximately $10-15 \%$ of neurons in the frontal cortex (Santana et al., 2009). Ongoing research in our group is testing whether these effects are cell-specific (only occurring in neurons expressing DA receptors) or if a non-cell specific mechanism leads to DA receptor-induced changes on neurite outgrowth in other subpopulations.

In contrast, application of D1-like receptor agonists to striatal neuronal cultures promotes neurite outgrowth, which can be blocked with D1-like receptor antagonists and is demonstrated in Figure 1B (Schmidt et al., 1996, 1998). This increased neurite outgrowth is associated with an increased number of growth cones and arborization (Schmidt et al., 1998). However, D2-like receptor activation shows no effect on striatal neurite outgrowth (also demonstrated in Figure 1B; Schmidt et al., 1996). Hence, D1-like receptor stimulation increases neurite outgrowth in the striatum in vitro.

Studies from intact brains bolster the importance of developmental DA receptor signaling on dendritic growth in DA-rich brain regions. Models of DA depletion (i.e., 6-OHDA treatment or mesencephalic lesion) show decreased expression of axon guidanceand cytoskeletal growth-related proteins as well as decreased length of pyramidal layer $\mathrm{V}$ basal dendrites in frontal cortex (Kalsbeek et al., 1989; Krasnova et al., 2007). In human studies, adolescents exposed prenatally to cocaine display changes in cortical thickness (Roussotte et al., 2012; Liu et al., 2013). MAP2 labeling of D1 receptor knockout mice and diolistic labeling of rabbits prenatally exposed to cocaine show abnormal apical dendrites of 
cortical pyramidal cells with decreased bundling and increased tortuous patterning (Jones et al., 2000; Stanwood et al., 2001a, 2005), which supports the increased basal neurite outgrowth observed in vitro. Conversely, silver impregnation of cortical neurons from D1 receptor overexpressing mice show decreased apical dendrite length compared to wild type littermates, which further supports a role for D1 receptor signaling to promote dendritic growth (Song et al., 2002). Finally, the Kellendonk lab has shown that mice overexpressing D2 receptors in the striatum have decreased complexity and length of striatal dendritic arbors (Cazorla et al., 2012). Although differences in normal striatal dendritic morphology have been studied based on receptor subtype expression (Gertler et al., 2008), to our knowledge the effects of reduced or absent D1 receptor signaling on striatal dendritic morphology has not been examined.

\section{SPINOGENESIS AND SYNAPTOGENESIS}

Dendritic spinous processes start to form at the beginning of synaptogenesis during the first postnatal week and peak in adolescence but continue to be structurally modified throughout adulthood (Zhang and Benson, 2000). Spines develop from dendritic filopodia that interact with incoming axons, but some data suggest that dendritic spines can form independent of axonal interaction (Zhang and Benson, 2000; Whitford et al., 2002; Yuste and Bonhoeffer, 2004). Dendritic spines are critical for synaptic plasticity, allowing for compartmentalization of post-synaptic signaling and synaptic specialization (Yuste and Bonhoeffer, 2001). Additionally, alterations in spine density likely originating during development are found in many neuropsychiatric diseases, such as autism and schizophrenia (Kaufmann and Moser, 2000; Garey, 2010; Penzes et al., 2011; Glausier and Lewis, 2013; Seshadri et al., 2013). Importantly, DA plays a role in spinogenesis. For example, a functional hyperdopaminergia, which occurs in DA transporter (DAT) knockout mice, leads to a loss of proximal dendritic spines in striatal projection neurons (Berlanga et al., 2011). This model also shows a behavioral phenotype of hyperactivity and anxiety as well as altered mesocortical circuitry (Zhang et al., 2010; Carpenter et al., 2012), and DA dysregulation occurs not only during development, but continues into adulthood in this model. Primate and rodent models of DA depletion also show decreases in striatal dendritic spines (Ingham et al., 1989; Neely et al., 2007; Villalba et al., 2009). Thus, a delicate balance of DA signaling is required for formation/stabilization of dendritic spines. Cortical pyramidal neurons of D1 and D2 receptor knockout mice exhibit decreased dendritic spine density (Wang et al., 2009), and moderate D1-like and D2-like receptor activation both have been shown to increase spine density and spinophillin expression in the striatum in vitro (Fasano et al., 2013). Studies have not yet shown if higher concentrations of DAergic agonists, more like the activation levels seen in the hyperdopaminergic DAT knockout mouse, would phenocopy the decreased dendritic spine density seen in that (potentially non-physiological) mutant. In fact, during adolescence $\mathrm{D} 2$ receptor activation decreases striatal dendritic spines (Jia et al., 2013). Interestingly, the spine loss in cortical pyramidal neurons resulting from DA depletion can be ameliorated by spinogenesis-promoting antipsychotics like clozapine, providing further support for spine dysfunction in the pathology of neuropsychiatric disease (Critchlow et al., 2006; Wang and Deutch, 2008).

Since dendritic spines serve as the recipients of synaptic input and both develop concurrently, spinogenesis and synaptogenesis are intimately connected and are often co-regulated (Zhang and Benson, 2000; Whitford et al., 2002; Yuste and Bonhoeffer, 2004; Haas, 2006). Multiple points of vulnerability beyond spine formation can be altered to disrupt synaptogenesis. Axonal pathfinding must lead to the vicinity of the target neuron for initial contact to be made. Cell-cell adhesion then needs to occur, followed by pre- and post-synaptic differentiation and synapse strengthening (Garner et al., 2002). Synapse formation, when it occurs properly, leads to the formation of connections on a particular part (usually dendritic spines) of a target neuron, sometimes over very long distances (Südhof, 2006). Schizophrenia and other neurodevelopmental disorders are at least in part, diseases of altered synaptic connectivity. Inappropriate dendritic arborization, spinogenesis, and synaptic connections lead to inappropriate connectivity and altered excitation-inhibition balance (McGlashan and Hoffman, 2000; Spronsen and Hoogenraad, 2010; Duman and Aghajanian, 2012). This is supported by observations of decreased dendritic spines and synaptic labeling in post mortem cortex of schizophrenic patients (Glantz and Lewis, 1997, 2000; Honer et al., 1999). Thus, synaptogenesis can be altered by any of the previously discussed developmental events and plays an important role in neuropsychiatric disease pathology.

Synaptogenesis follows a similar timeline of development as spinogenesis and displays similar responses to DAergic modulation. Synapses begin to form during the first postnatal week (Hattori and McGeer, 1973). The number of synapses peak during adolescence, which is followed by synaptic pruning (Zhang and Benson, 2000). In the striatum and frontal cortex, electron microscopy has shown that DAergic axons form symmetric synapses similar to most GABAergic interneurons whereas glutamatergic pyramidal axons forms asymmetric synapses (Smiley et al., 1992; Antonopoulos etal., 2002; Yokofujita et al., 2008). Neonatal DA depletion decreases the number of symmetric synapses and changes the structure of asymmetric synapses (Onténiente et al., 1980; Tennyson et al., 1982; Ingham et al., 1991, 1993). Others have suggested that neonatal DA depletion can alter dendritic structures in the frontal cortex (Sherren and Pappas, 2005), and cause dysregulation of gene expression patterns required for normal brain architecture (Krasnova et al., 2007). DA receptor antagonists can decrease prefrontal synapse density whereas agonists slightly increased density (Sugahara and Shiraishi, 1998). Furthermore, haloperidol, a D2-like receptor antagonist, decreases hippocampal synaptic density in vitro (Critchlow et al., 2006). Opposing D1 vs. D2 receptor developmental effects are lost with regards to spinogenesis and synaptogenesis, and hopefully further study will produce a mechanistic explanation. DA lesion studies in adult animals support a continued role for DA in the maintenance of corticostriatal synapses in the striatum (for a comprehensive review of DA-regulated morphological and electrophysiological changes, please see Arbuthnott et al., 2000 and Surmeier et al., 2011). Taken together, these studies support a crucial role for DA in formation and stabilization of synaptic 
connections in the striatum and frontal cortex, providing further evidence for developmental disruptions of DA and other neurotransmitters in the structural pathology of neuropsychiatric disease.

\section{DOPAMINE D1 RECEPTOR SIGNALING MECHANISMS IN DEVELOPMENTAL PROCESSES}

Establishing a detailed signaling mechanism for the above mentioned in vitro and in vivo effects on developmental processes is complicated by multiple signaling cascades and receptor interactions. While all five DA receptors likely contribute to these effects in specific ways, studies to date have predominantly examined D1 receptors, and thus our discussion will also focus there. In general, D1-like receptors transduce their signals by activating adenylyl cyclase and increasing intracellular cAMP via Gas/Gaolf coupled proteins. Conversely, D2-like receptors typically transduce their signals by inhibiting adenylyl cyclase and decreasing cAMP (Missale etal., 1998; Beaulieu and Gainetdinov, 2011). Intracellular cAMP activates protein kinase A (PKA), which phosphorylates proteins such as DA and cAMP-regulated phosphoprotein (DARPP-32) and cAMP responsive-element binding protein (CREB; Parker et al., 1996; Greengard et al., 1999). CREB promotes transcription of genes with cAMP response elements. Additionally, MAPKs like extracellular signal-related kinase (ERK) are activated by D1 receptor stimulation and increase CREB signaling (Missale et al., 1998).

DA receptors also participate in multiple non- $\mathrm{G} \alpha$ protein signaling mechanisms. DA receptor mediated effects can involve G $\beta / G \gamma$ proteins as well as other receptors (Missale et al., 1998; Beaulieu and Gainetdinov, 2011). For example, D1 receptors interact with NMDA receptors (Lee et al., 2002; Nai et al., 2010), adenosine receptors (Fuxe et al., 2007; Shen et al., 2013), and neurotrophin TrkB receptors (Iwakura et al., 2008), among others. $\mathrm{D} 2$ receptors complex with adenosine $\mathrm{A}_{2 A}$ receptors (Canals et al., 2003) and sigma-1 receptors (Navarro et al., 2013) and recruit protein kinase B/glycogen synthase kinase 3 (AKT/GSK3) signaling pathways via a slower, cAMP-independent signaling mechanism (Beaulieu et al., 2005, 2007). G protein-coupled receptor kinases and arrestins, normally associated with receptor desensitization, form a scaffold for D2 receptor interactions with protein phosphatase $2 \mathrm{~A}$ and AKT. The resulting dephosphorylation of AKT increases activity of GSK3, a target of lithium and many antipsychotic drugs (Beaulieu et al., 2004; Li et al., 2007; Lovestone et al., 2007).

Given the profound differences between how neurites of cortical and striatal neurons respond to DA receptor agonists, it is likely that intracellular signals are regulated in cell-specific ways. These are difficult experiments to carry out, however, and we currently have a fairly superficial understanding of these mechanisms. Both D1-like receptor agonists and PKA activators increase cortical MAP2 phosphorylation, decreasing the ability of MAP2 to stabilize the dendritic cytoskeleton and thus decreasing neurite outgrowth (Song et al., 2002). Neurite outgrowth facilitation by D1-like receptor stimulation in the striatum is also PKAdependent and at least in part CREB-mediated (Schmidt et al., 1998). Additionally, the Chao lab has demonstrated that increased neurite outgrowth in striatal cultures is at least partially dependent on D1 receptor-mediated neurotrophin TrkB receptor activation. Their study showed that D1-like receptor agonist treatment in primary striatal cultures leads to activation and increased surface expression of the TrkB receptor, and is accompanied by phosphorylation of downstream Trk signaling proteins (Iwakura et al., 2008). Thus, taken together, current evidence suggests that the D1-like receptor-mediated changes in neurite outgrowth are PKA-dependent in both cortex and striatum with an additional neurotrophin TrkB receptor-dependent component only in the striatum. The dichotomy between D1 and D2 receptor signaling in the context of developmental dysfunction needs to be understood in order to target the neurodevelopmental origins of neuropsychiatric disease. Furthermore, future studies should identify potential roles for differences in $\mathrm{G}$ protein coupling (e.g., Gas in cortex and Gaolf in striatum Herve et al., 1993; Herve, 2011), and accessory proteins with differential expression patterns (e.g., GPR88 in striatum Logue et al., 2009; Van Waes et al., 2011; Marley et al., 2013).

\section{GENETIC DISRUPTIONS OF DA SIGNALING AND NEUROPSYCHIATRIC DISEASE}

The DA system plays a fundamental role in psychotic disorders, with D2 receptor antagonism being a major target for both typical and atypical antipsychotics. While D2 receptor antagonism may be useful in controlling many of the positive symptoms in schizophrenia, emerging data implicates D1-like receptors as a target for negative symptoms in schizophrenia (Goldman-Rakic et al., 2004; Arnsten, 2013). In addition, several genetic perturbations in DArelated genes have been found in patients with neuropsychiatric disease. Patients with 22q11 deletion syndrome, which disrupts DA-related genes (e.g., catechol-O-methyltransferase, COMT) among others have an increased risk for neuropsychiatric disorders, including schizophrenia-like psychosis, autism, and anxiety disorders (Karam et al., 2010; Jonas et al., 2013). Hypomethylation of the COMT gene, which leads to an increase in the enzyme that breaks down DA, has been associated with schizophrenia and bipolar disorder (Abdolmaleky et al., 2006; Nohesara et al., 2011). The translocation in the gene disrupted in schizophrenia1 (DISC-1) was originally found in a large Scottish family with abnormally high rates of neuropsychiatric disease (Millar et al., 2001). Interestingly, knockdown of DISC-1 in animal models causes altered DAergic maturation and behavioral changes associated with altered prefrontal cortex circuitry, suggesting a role for DA in DISC-1 associated neuropsychiatric disease (Niwa et al., 2010). Association studies implicate the A1 allele of the Taq1 polymorphism of DRD2 in the development of Tourette's syndrome, ADHD, autism, PTSD, and alcoholism (Comings et al., 1991). The Holden lab has found DA-related genes (DRD1, DRD2, and $P P P 1 R 1 B)$ associated with the severity of autism in families with males only affected (Hettinger et al., 2008, 2012). Others have found polymorphisms in DRD3 and DRD4 associated with autism severity (de Krom et al., 2009; Gadow et al., 2010; Staal et al., 2012) and DAT polymorphisms linked to both ADHD and bipolar disorder (Sharp et al., 2009). Additionally, polymorphisms in the gene encoding the downstream signaling protein Akt are associated with both bipolar disorder and schizophrenia (Thiselton et al., 2008; Karege et al., 2012). While the effect sizes in these studies are not 
large, and the link to DA is sometimes indirect, taken together these findings emphasize that disrupted DAergic homeostasis may be a central mechanism in the risk of developing a neuropsychiatric disorder.

\section{CONCLUSION}

There is strong evidence that DA plays a critical role in the generation of typical brain structure and function. DA and its cognate receptors are present in the striatum and frontal cortex early in brain development and contribute to the development of pathways needed for movement, cognition, and reward. Altered DA signaling can affect the proliferation, migration, and differentiation of specific subpopulations of neurons, and thus impact frontal cortex and striatal neurocircuitry. D1 and D2 receptor subtypes often have opposing effects on these developmental processes, and the underlying mechanism for this dichotomy as well as the signaling pathways that mediate these subtype-specific effects remain mostly unknown.

Yet, DA is not the only neuromodulator that plays a role in developmental processes. Serotonin is present before synaptogenesis (Hansson etal., 1998) and alters neurite outgrowth and axon pathfinding in vitro in a receptor-dependent manner (Lotto et al., 1999; Persico et al., 2006; Bonnin et al., 2007; Tajiri et al., 2012; Trakhtenberg and Goldberg, 2012; Anelli et al., 2013; Speranza et al., 2013; for comprehensive review of roles of serotonin in development, see van Kesteren and Spencer, 2003; Pino et al., 2004; Bonnin and Levitt, 2011; Trowbridge et al., 2011). In addition, decreased cortical thickness in reelin mutants is postulated to be driven by cortical cholinergic deprivation (Liu et al., 2001; Sigala et al., 2007), and both nicotinic and muscarinic cholinergic receptor manipulation alters neurite outgrowth (Lipton etal., 1988; Pugh and Berg, 1994; Small et al., 1995; for comprehensive review, see Ruediger and Bolz, 2007; Dwyer et al., 2009; Bruel-Jungerman et al., 2011). Finally, noradrenergic neurons are thought form early synapses in the cortical plate and mediate neuronal migration and laminar formation (Herlenius and Lagercrantz, 2001). DA thus does not provide a singular role in these developmental processes, and future studies will need to address additional neuromodulators in combinatorial patterns.

Our understanding of the role of developmental disruptions of DA in the pathology of neuropsychiatric disorders is still maturing. DA-rich areas, such as the prefrontal cortex and striatum, are clearly dysfunctional in neuropsychiatric disorders like schizophrenia, substance use disorders, and ADHD (Arnsten, 2006, 2011; Leppanen, 2006; Andersen and Teicher, 2009; Arnsten et al., 2012). Developmental alterations in dendritic growth and/or GABAergic interneuron migration likely contribute to the development of pathology in these disorders (Beasley and Reynolds, 1997; Kaufmann and Moser, 2000; Black et al., 2004; Curley et al., 2011). The increased DAergic influence in the cortex of primates and dysfunction of DA-rich cortical areas in neuropsychiatric disorders suggests an evolutionally increased role of DA, which has also resulted in an evolutionarily increased vulnerability to disease. A new era of neuropsychiatric pharmacologic targets should address the underlying pathology resulting from developmental disruptions in DA and other neurotransmitters. Importantly, early interventions have the most positive impacts in neurodevelopmental disorders and learning disabilities (Bradshaw et al., 2012); our hope is that a detailed mechanistic understanding of brain substrates and developmental pharmacology will allow clinicians to make similar rational interventions within neuropsychiatry.

\section{ACKNOWLEDGMENTS}

We thank Devon Graham, Emily Ross, and Pratik Talati for helping to edit the manuscript and Deirdre McCarthy for contributing artwork. We also thank Kylie Beck for our illustrations; this service is supported by P30HD15052. This work is supported by RO1MH086629 (Gregg D. Stanwood) and the Vanderbilt MSTP program.

\section{REFERENCES}

Abdolmaleky, H. M., Cheng, K. H., Faraone, S. V., Wilcox, M., Glatt, S. J., Gao, F., et al. (2006). Hypomethylation of MB-COMT promoter is a major risk factor for schizophrenia and bipolar disorder. Hum. Mol. Genet. 15, 3132-3145. doi: 10.1093/hmg/ddl253

Ade, K. K., Wan, Y., Chen, M., Gloss, B., and Calakos, N. (2011). A improved BAC transgenic fluorescent reporter line for sensitive and specific identification of striatonigral medium spiny neurons. Front. Syst. Neurosci. 5:32. doi: 10.3389/fnsys.2011.00032

Akil, M., Pierri, J. N., Whitehead, R. E., Edgar, C. L., Mohila, C., Sampson, A. R., et al. (1999). Lamina-specific alterations in the dopamine innervation of the prefrontal cortex in schizophrenic subjects. Am. J. Psychiatry 156, 1580-1589.

Alonso, S. J., Navarro, E., and Rodriguez, M. (1994). Permanent dopaminergic alterations in the n. accumbens after prenatal stress. Pharmacol. Biochem. Behav. 49, 353-358. doi: 10.1016/0091-3057(94)90433-2

Andersen, S. L., Arvanitogiannis, A., Pliakas, A. M., Leblanc, C., and Carlezon, W. A. Jr. (2002). Altered responsiveness to cocaine in rats exposed to methylphenidate during development. Nat. Neurosci. 5, 13-14. doi: 10.1038/nn777

Andersen, S. L., and Teicher, M. H. (2009). Desperately driven and no brakes: developmental stress exposure and subsequent risk for substance abuse. Neurosci. Biobehav. Rev. 33, 516-524. doi: 10.1016/j.neubiorev.2008.09.009

Andersen, S. L., Thompson, A. T., Rutstein, M., Hostetter, J. C., and Teicher, M. H. (2000). Dopamine receptor pruning in prefrontal cortex during the periadolescent period in rats. Synapse 37, 167-169.

Anelli, T., Cardarelli, S., Ori, M., Nardi, I., Biagioni, S., and Poiana, G. (2013). 5-Hydroxytryptamine $1 \mathrm{~A}$ and $2 \mathrm{~B}$ serotonin receptors in neurite outgrowth: involvement of early growth response protein 1. Dev. Neurosci. doi: 10.1159/000354423 [Epub ahead of print].

Antonopoulos, J., Dori, I., Dinopoulos, A., Chiotelli, M., and Parnavelas, J. G. (2002). Postnatal development of the dopaminergic system of the striatum in the rat. Neuroscience 110, 245-256. doi: 10.1016/S0306-4522(01)00575-9

Araki, K. Y., Sims, J. R., and Bhide, P. G. (2007). Dopamine receptor mRNA and protein expression in the mouse corpus striatum and cerebral cortex during pre- and postnatal development. Brain Res. 1156, 31-45. doi: 10.1016/j.brainres.2007.04.043

Arbuthnott, G. W., Ingham, C. A., and Wickens, J. R. (2000). Dopamine and synaptic plasticity in the neostriatum. J. Anat. 196 (Pt 4), 587-596. doi: 10.1046/j.14697580.2000.19640587.x

Arnsten, A. F. (2006). Fundamentals of attention-deficit/hyperactivity disorder: circuits and pathways. J. Clin. Psychiatry 67(Suppl. 8), 7-12.

Arnsten, A. F. (2011). Prefrontal cortical network connections: key site of vulnerability in stress and schizophrenia. Int. J. Dev. Neurosci. 29, 215-223. doi: 10.1016/j.ijdevneu.2011.02.006

Arnsten, A. F. (2013). The neurobiology of thought: the groundbreaking discoveries of Patricia Goldman-Rakic 1937-2003. Cereb. Cortex 23, 2269-2281. doi: 10.1093/cercor/bht195

Arnsten, A. F., Wang, M. J., and Paspalas, C. D. (2012). Neuromodulation of thought: flexibilities and vulnerabilities in prefrontal cortical network synapses. Neuron 76 , 223-239. doi: 10.1016/j.neuron.2012.08.038

Beasley, C. L., and Reynolds, G. P. (1997). Parvalbumin-immunoreactive neurons are reduced in the prefrontal cortex of schizophrenics. Schizophr. Res. 24, 349-355. doi: 10.1016/S0920-9964(96)00122-3 
Beaulieu, J. M., and Gainetdinov, R. R. (2011). The physiology, signaling, and pharmacology of dopamine receptors. Pharmacol. Rev. 63, 182-217. doi: 10.1124/pr.110.002642

Beaulieu, J. M., Gainetdinov, R. R., and Caron, M. G. (2007). The Akt-GSK-3 signaling cascade in the actions of dopamine. Trends Pharmacol. Sci. 28, 166-172. doi: 10.1016/j.tips.2007.02.006

Beaulieu, J. M., Sotnikova, T. D., Marion, S., Lefkowitz, R. J., Gainetdinov, R. R., and Caron, M. G. (2005). An Akt/beta-arrestin 2/PP2A signaling complex mediates dopaminergic neurotransmission and behavior. Cell 122, 261-273. doi: 10.1016/j.cell.2005.05.012

Beaulieu, J. M., Sotnikova, T. D., Yao, W. D., Kockeritz, L., Woodgett, J. R., Gainetdinov, R. R., et al. (2004). Lithium antagonizes dopamine-dependent behaviors mediated by an AKT/glycogen synthase kinase 3 signaling cascade. Proc. Natl. Acad. Sci. U.S.A. 101, 5099-5104. doi: 10.1073/pnas.0307921101

Bellone, C., Mameli, M., and Luscher, C. (2011). In Utero exposure to cocaine delays postnatal synaptic maturation of glutamatergic transmission in the VTA. Nat. Neurosci. 14, 1439-1446. doi: 10.1038/nn.2930

Ben-Ari, Y. (2013). Neuropaediatric and neuroarchaeology: understanding development to correct brain disorders. Acta Paediatr. 102, 331-334. doi: 10.1111/apa.12161

Berger, B., Gaspar, P., and Verney, C. (1991). Dopaminergic innervation of the cerebral cortex: unexpected differences between rodents and primates. Trends Neurosci. 14, 21-27. doi: 10.1016/0166-2236(91)90179-X

Berger, B., Trottier, S., Verney, C., Gaspar, P., and Alvarez, C. (1988). Regional and laminar distribution of the dopamine and serotonin innervation in the macaque cerebral cortex: a radioautographic study. J. Comp. Neurol. 273, 99-119. doi: 10.1002/cne.902730109

Berger, M. A., Barros, V. G., Sarchi, M. I., Tarazi, F. I., and Antonelli, M. C. (2002). Long-term effects of prenatal stress on dopamine and glutamate receptors in adult rat brain. Neurochem. Res. 27, 1525-1533. doi: 10.1023/A:10216566 07278

Berlanga, M. L., Price, D. L., Phung, B. S., Giuly, R., Terada, M., Yamada, N., et al. (2011). Multiscale imaging characterization of dopamine transporter knockout mice reveals regional alterations in spine density of medium spiny neurons. Brain Res. 1390, 41-49. doi: 10.1016/j.brainres.2011.03.044

Bhide, P. G. (2009). Dopamine, cocaine and the development of cerebral cortical cytoarchitecture: a review of current concepts. Semin. Cell Dev. Biol. 20, 395-402. doi: 10.1016/j.semcdb.2009.01.006

Bjorklund, A., and Dunnett, S. B. (2007). Dopamine neuron systems in the brain: an update. Trends Neurosci. 30, 194-202. doi: 10.1016/j.tins.2007.03.006

Black, J. E., Kodish, I. M., Grossman, A. W., Klintsova, A. Y., Orlovskaya, D., Vostrikov, V., et al. (2004). Pathology of layer V pyramidal neurons in the prefrontal cortex of patients with schizophrenia. Am. J. Psychiatry 161, 742-744. doi: 10.1176/appi.ajp.161.4.742

Bonnin, A., and Levitt, P. (2011). Fetal, maternal, and placental sources of serotonin and new implications for developmental programming of the brain. Neuroscience 197, 1-7. doi: 10.1016/j.neuroscience.2011.10.005

Bonnin, A., Torii, M., Wang, L., Rakic, P., and Levitt, P. (2007). Serotonin modulates the response of embryonic thalamocortical axons to netrin-1. Nat. Neurosci. 10, 588-597. doi: 10.1038/nn1896

Bosboom, J. L. W., Stoffers, D., and Wolters, E. C. (2004). Cognitive dysfunction and dementia in Parkinson's disease. J. Neural Transm. 111, 1303-1315. doi: 10.1007/s00702-004-0168-161

Boyson, S. J., Mcgonigle, P., and Molinoff, P. B. (1986). Quantitative autoradiographic localization of the D1 and D2 subtypes of dopamine receptors in rat brain. J. Neurosci. 6, 3177-3188.

Bradshaw, C. P., Goldweber, A., Fishbein, D., and Greenberg, M. T. (2012). Infusing developmental neuroscience into school-based preventive interventions: implications and future directions. J. Adolesc. Health 51, S41-S47. doi: 10.1016/j.jadohealth.2012.04.020

Brenhouse, H. C., Sonntag, K. C., and Andersen, S. L. (2008). Transient D1 dopamine receptor expression on prefrontal cortex projection neurons: relationship to enhanced motivational salience of drug cues in adolescence. J. Neurosci. 28, 2375-2382. doi: 10.1523/jneurosci.5064-07.2008

Brown, R. W., Maple, A. M., Perna, M. K., Sheppard, A. B., Cope, Z. A., and Kostrzewa, R. M. (2012). Schizophrenia and substance abuse comorbidity: nicotine addiction and the neonatal quinpirole model. Dev. Neurosci. 34, 140-151. doi: $10.1159 / 000338830$
Bruel-Jungerman, E., Lucassen, P. J., and Francis, F. (2011). Cholinergic influences on cortical development and adult neurogenesis. Behav. Brain Res. 221, 379-388. doi: 10.1016/j.bbr.2011.01.021

Canals, M., Marcellino, D., Fanelli, F., Ciruela, F., De Benedetti, P., Goldberg, S. R., et al. (2003). Adenosine A2A-dopamine D2 receptor-receptor heteromerization: qualitative and quantitative assessment by fluorescence and bioluminescence energy transfer. J. Biol. Chem. 278, 46741-46749. doi: 10.1074/jbc.M306451200

Carpenter, A. C., Saborido, T. P., and Stanwood, G. D. (2012). Development of hyperactivity and anxiety responses in dopamine transporter-deficient mice. Dev. Neurosci. 34, 250-257. doi: 10.1159/000336824

Carter, C. S., Perlstein, W., Ganguli, R., Brar, J., Mintun, M., and Cohen, J. D. (1998). Functional hypofrontality and working memory dysfunction in schizophrenia. Am. J. Psychiatry 155, 1285-1287.

Cazorla, M., Shegda, M., Ramesh, B., Harrison, N. L., and Kellendonk, C. (2012). Striatal D2 receptors regulate dendritic morphology of medium spiny neurons via Kir2 channels. J. Neurosci. 32, 2398-2409. doi: 10.1523/jneurosci.6056-11.2012

Comings, D. E., Comings, B. G., Muhleman, D., Dietz, G., Shahbahrami, B., Tast, D., et al. (1991). The dopamine D2 receptor locus as a modifying gene in neuropsychiatric disorders. JAMA 266, 1793-1800. doi: 10.1001/jama.1991.03470130073032

Cornew, L., Roberts, T. P., Blaskey, L., and Edgar, J. C. (2012). Resting-state oscillatory activity in autism spectrum disorders. J. Autism Dev. Disord. 42, 1884-1894. doi: 10.1007/s10803-011-1431-1436

Couppis, M. H., Kennedy, C. H., and Stanwood, G. D. (2008). Differences in aggressive behavior and in the mesocorticolimbic DA system between A/J and BALB/cJ mice. Synapse 62, 715-724. doi: 10.1002/syn.20545

Crandall, J. E., Hackett, H. E., Tobet, S. A., Kosofsky, B. E., and Bhide, P. G. (2004). Cocaine exposure decreases GABA neuron migration from the ganglionic eminence to the cerebral cortex in embryonic mice. Cereb. Cortex 14, 665-675. doi: 10.1093/cercor/bhh027

Crandall, J. E., Mccarthy, D. M., Araki, K. Y., Sims, J. R., Ren, J.-Q., and Bhide, P. G. (2007). Dopamine receptor activation modulates GABA neuron migration from the basal forebrain to the cerebral cortex. J. Neurosci. 27, 3813-3822. doi: 10.1523/JNEUROSCI.5124-06.2007

Critchlow, H. M., Maycox, P. R., Skepper, J. N., and Krylova, O. (2006). Clozapine and haloperidol differentially regulate dendritic spine formation and synaptogenesis in rat hippocampal neurons. Mol. Cell. Neurosci. 32, 356-365. doi: 10.1016/j.mcn.2006.05.007

Curley, A. A., Arion, D., Volk, D. W., Asafu-Adjei, J. K., Sampson, A. R., Fish, K. N., et al. (2011). Cortical deficits of glutamic acid decarboxylase 67 expression in schizophrenia: clinical, protein, and cell type-specific features. Am. J. Psychiatry 168, 921-929. doi: 10.1176/appi.ajp.2011.11010052

de Carlos, J. A., Lopez-Mascaraque, L., and Valverde, F. (1996). Dynamics of cell migration from the lateral ganglionic eminence in the rat. J. Neurosci. 16, 61466156.

de Krom, M., Staal, W. G., Ophoff, R. A., Hendriks, J., Buitelaar, J., Franke, B., et al. (2009). A common variant in DRD3 receptor is associated with autism spectrum disorder. Biol. Psychiatry 65, 625-630. doi: 10.1016/j.biopsych.2008.09.035

Denhardt, D. T. (1999). "Signal transduction pathways and regulation of the mammalian cell cycle: cell type-dependent integration of external signals," in The Molecular Basis of Cell Cycle and Growth Control, ed. G. S. Stein (New York: Wiley-Liss), 225-304.

D'Haenen H, A., and Bossuyt, A. (1994). Dopamine D2 receptors in depression measured with single photon emission computed tomography. Biol. Psychiatry 35, 128-132. doi: 10.1016/0006-3223(94)91202-5

Di Forti, M., Lappin, J. M., and Murray, R. M. (2007). Risk factors for schizophreniaall roads lead to dopamine. Eur. Neuropsychopharmacol. 17(Suppl. 2), S101-S107. doi: 10.1016/j.euroneuro.2007.02.005

Duman, R. S., and Aghajanian, G. K. (2012). Synaptic dysfunction in depression: potential therapeutic targets. Science 338, 68-72. doi: 10.1126/science.1222939

Dwyer, J. B., Mcquown, S. C., and Leslie, F. M. (2009). The dynamic effects of nicotine on the developing brain. Pharmacol. Ther. 122, 125-139. doi: 10.1016/j.pharmthera.2009.02.003

Egeland, M., Zhang, X., Millan, M. J., Mocaer, E., and Svenningsson, P. (2012). Pharmacological or genetic blockade of the dopamine D3 receptor increases cell proliferation in the hippocampus of adult mice. J. Neurochem. 123, 811-823. doi: 10.1111 /jnc. 12011

Fasano, C., Bourque, M. J., Lapointe, G., Leo, D., Thibault, D., Haber, M., et al. (2013). Dopamine facilitates dendritic spine formation by cultured 
striatal medium spiny neurons through both D1 and D2 dopamine receptors. Neuropharmacology 67, 432-443. doi: 10.1016/j.neuropharm.2012.11.030

Finlay, J. M. (2001). Mesoprefrontal dopamine neurons and schizophrenia: role of developmental abnormalities. Schizophr. Bull. 27, 431-442. doi: 10.1093/oxfordjournals.schbul.a006885

Frederick, A. L., and Stanwood, G. D. (2009). Drugs, biogenic amine targets and the developing brain. Dev. Neurosci. 31, 7-22. doi: 10.1159/000207490

Fuxe, K., Ferre, S., Genedani, S., Franco, R., and Agnati, L. F. (2007). Adenosine receptor-dopamine receptor interactions in the basal ganglia and their relevance for brain function. Physiol. Behav. 92, 210-217. doi: 10.1016/j.physbeh.2007.05.034

Gadow, K. D., Devincent, C. J., Olvet, D. M., Pisarevskaya, V., and Hatchwell, E. (2010). Association of DRD4 polymorphism with severity of oppositional defiant disorder, separation anxiety disorder and repetitive behaviors in children with autism spectrum disorder. Eur. J. Neurosci. 32, 1058-1065. doi: 10.1111/j.14609568.2010.07382.x

Garey, L. (2010). When cortical development goes wrong: schizophrenia as a neurodevelopmental disease of microcircuits. J. Anat. 217, 324-333. doi: 10.1111/j.1469-7580.2010.01231.x

Garner, C. C., Zhai, R. G., Gundelfinger, E. D., and Ziv, N. E. (2002). Molecular mechanisms of CNS synaptogenesis. Trends Neurosci. 25, 243-250. doi: 10.1016/S0166-2236(02)02152-5

Gaspar, P., Berger, B., Febvret, A., Vigny, A., and Henry, J. P. (1989). Catecholamine innervation of the human cerebral cortex as revealed by comparative immunohistochemistry of tyrosine hydroxylase and dopamine-beta-hydroxylase. J. Comp. Neurol. 279, 249-271. doi: 10.1002/cne.902790208

Gertler, T. S., Chan, C. S., and Surmeier, D. J. (2008). Dichotomous anatomical properties of adult striatal medium spiny neurons. J. Neurosci. 28, 10814-10824. doi: 10.1523/jneurosci.2660-08.2008

Glantz, L. A., and Lewis, D. A. (1997). Reduction of synaptophysin immunoreactivity in the prefrontal cortex of subjects with schizophrenia: regional and diagnostic specificity. Arch. Gen. Psychiatry 54, 660-669. doi: 10.1001/archpsyc. 1997.01830190088009

Glantz, L. A., and Lewis, D. A. (2000). Decreased dendritic spine density on prefrontal cortical pyramidal neurons in schizophrenia. Arch. Gen. Psychiatry 57, 65-73. doi: 10.1001/archpsyc.57.1.65

Glausier, J. R., and Lewis, D. A. (2013). Dendritic spine pathology in schizophrenia. Neuroscience 251, 90-107. doi: 10.1016/j.neuroscience.2012.04.044

Goldman-Rakic, P., Castner, S., Svensson, T., Siever, L., and Williams, G. (2004). Targeting the dopamine D1 receptor in schizophrenia: insights for cognitive dysfunction. Psychopharmacology 174, 3-16. doi: 10.1007/s00213-004-1793-y

Gong, S., Zheng, C., Doughty, M. L., Losos, K., Didkovsky, N., Schambra, U. B., et al. (2003). A gene expression atlas of the central nervous system based on bacterial artificial chromosomes. Nature 425, 917-925. doi: 10.1038/nature02033

Greengard, P., Allen, P. B., and Nairn, A. C. (1999). Beyond the dopamine receptor: the DARPP-32/protein phosphatase-1 cascade. Neuron 23, 435-447. doi: 10.1016/S0896-6273(00)80798-9

Gurevich, E. V., and Joyce, J. N. (2000). Dopamine D(3) receptor is selectively and transiently expressed in the developing whisker barrel cortex of the rat. J. Comp. Neurol. 420, 35-51. doi: 10.1002/(SICI)1096-9861(20000424)420:1<35::AIDCNE3>3.0.CO;2-K

Gurevich, E. V., Robertson, R. T., and Joyce, J. N. (2001). Thalamo-cortical afferents control transient expression of the dopamine $\mathrm{D}(3)$ receptor in the rat somatosensory cortex. Cereb. Cortex 11, 691-701. doi: 10.1093/cercor/11.8.691

Haas, K. (2006). "Role of synaptogenesis in morphologic stabilization of developing dendrites," in Molecular Mechanisms of Synaptogenesis, eds A. Dityatev and A. El-Husseini (USA: Springer), 297-309.

Hamilton, L. R., Czoty, P. W., and Nader, M.A. (2011). Behavioral characterization of adult male and female rhesus monkeys exposed to cocaine throughout gestation. Psychopharmacology (Berl.) 213, 799-808. doi: 10.1007/s00213-010-2038-x

Han, X., Li, N., Xue, X., Shao, F., and Wang, W. (2012). Early social isolation disrupts latent inhibition and increases dopamine D2 receptor expression in the medial prefrontal cortex and nucleus accumbens of adult rats. Brain Res. 1447, 38-43. doi: 10.1016/j.brainres.2012.01.058

Hansen, D. V., Lui, J. H., Flandin, P., Yoshikawa, K., Rubenstein, J. L., Alvarez-Buylla, A., etal. (2013). Non-epithelial stem cells and cortical interneuron production in the human ganglionic eminences. Nat. Neurosci. 16, 1576-1587. doi: $10.1038 / \mathrm{nn} .3541$
Hansson, S. R., Mezey, E., and Hoffman, B. J. (1998). Serotonin transporter messenger RNA in the developing rat brain: early expression in serotonergic neurons and transient expression in non-serotonergic neurons. Neuroscience 83, 1185-1201. doi: 10.1016/S0306-4522(97)00444-2

Harada, M., Taki, M. M., Nose, A., Kubo, H., Mori, K., Nishitani, H., et al. (2011). Non-invasive evaluation of the GABAergic/glutamatergic system in autistic patients observed by MEGA-editing proton MR spectroscopy using a clinical 3 tesla instrument. J. Autism Dev. Disord. 41, 447-454. doi: 10.1007/s10803-010-1065-1060

Hattori, T., and McGeer, P. L. (1973). Synaptogenesis in the corpus striatum of infant rat. Exp. Neurol. 38, 70-79. doi: 10.1016/0014-4886(73)90008-3

Herlenius, E., and Lagercrantz, H. (2001). Neurotransmitters and neuromodulators during early human development. Early Hum. Dev. 65, 21-37. doi: 10.1016/S0378-3782(01)00189-X

Herve, D. (2011). Identification of a specific assembly of the $g$ protein golf as a critical and regulated module of dopamine and adenosine-activated cAMP pathways in the striatum. Front. Neuroanat. 5:48. doi: 10.3389/fnana.2011. 00048

Herve, D., Levi-Strauss, M., Marey-Semper, I., Verney, C., Tassin, J. P., Glowinski, J., et al. (1993). G(olf) and Gs in rat basal ganglia: possible involvement of G(olf) in the coupling of dopamine D1 receptor with adenylyl cyclase. J. Neurosci. 13, 2237-2248.

Hettinger, J. A., Liu, X., Hudson, M. L., Lee, A., Cohen, I. L., Michaelis, R. C., et al. (2012). DRD2 and PPP1R1B (DARPP-32) polymorphisms independently confer increased risk for autism spectrum disorders and additively predict affected status in male-only affected sib-pair families. Behav. Brain Funct. 8, 19. doi: 10.1186/1744-9081-8-19

Hettinger, J. A., Liu, X., Schwartz, C. E., Michaelis, R. C., and Holden, J. J. (2008). A DRD1 haplotype is associated with risk for autism spectrum disorders in maleonly affected sib-pair families. Am. J. Med. Genet. B Neuropsychiatry Genet. 147B, 628-636. doi: 10.1002/ajmg.b.30655

Honer, W. G., Falkai, P., Chen, C., Arango, V., Mann, J. J., and Dwork, A. J. (1999). Synaptic and plasticity-associated proteins in anterior frontal cortex in severe mental illness. Neuroscience 91, 1247-1255. doi: 10.1016/S0306-4522(98)00679-4

Ingham, C. A., Hood, S. H., and Arbuthnott, G. W. (1989). Spine density on neostriatal neurones changes with 6-hydroxydopamine lesions and with age. Brain Res. 503, 334-338. doi: 10.1016/0006-8993(89)91686-7

Ingham, C. A., Hood, S. H., and Arbuthnott, G. W. (1991). A light and electron microscopical study of enkephalin-immunoreactive structures in the rat neostriatum after removal of the nigrostriatal dopaminergic pathway. Neuroscience 42, 715-730. doi: 10.1016/0306-4522(91)90040-U

Ingham, C. A., Hood, S. H., Maldegem, B., Weenink, A., and Arbuthnott, G. W. (1993). Morphological changes in the rat neostriatum after unilateral 6hydroxydopamine injections into the nigrostriatal pathway. Exp. Brain Res. 93, 17-27. doi: 10.1007/bf00227776

Iwakura, Y., Nawa, H., Sora, I., and Chao, M. V. (2008). Dopamine D1 receptorinduced signaling through TrkB receptors in striatal neurons. J. Biol. Chem. 283, 15799-15806. doi: 10.1074/jbc.M801553200

Jia, J. -M., Zhao, J., Hu, Z., Lindberg, D., and Li, Z. (2013). Age-dependent regulation of synaptic connections by dopamine D2 receptors. Nat. Neurosci. 16, 1627-1636. doi: $10.1038 / \mathrm{nn} .3542$

Jonas, R. K., Montojo, C. A., and Bearden, C. E. (2013). The 22q11.2 deletion syndrome as a window into complex neuropsychiatric disorders over the lifespan. Biol. Psychiatry doi: 10.1016/j.biopsych.2013.07.019 [Epub ahead of print].

Jones, L. B., Stanwood, G. D., Reinoso, B. S., Washington, R. A., Wang, H.-Y., Friedman, E., et al. (2000). In utero cocaine-induced dysfunction of dopamine D1 receptor signaling and abnormal differentiation of cerebral cortical neurons. J. Neurosci. 20, 4606-4614.

Jung, A. B., and Bennett, J. P. Jr. (1996). Development of striatal dopaminergic function. I. Pre- and postnatal development of mRNAs and binding sites for striatal D1 (D1a) and D2 (D2a) receptors. Brain Res. Dev. Brain Res. 94, 109-120.

Kalivas, P. W., Volkow, N., and Seamans, J. (2005). Unmanageable motivation in addiction: a pathology in prefrontal-accumbens glutamate transmission. Neuron 45, 647-650. doi: 10.1016/j.neuron.2005.02.005

Kalsbeek, A., Matthijssen, M. A. H., and Uylings, H. B. M. (1989). Morphometric analysis of prefrontal cortical development following neonatal lesioning of the dopaminergic mesocortical projection. Exp. Brain Res. 78, 279-289. doi: 10.1007/bf00228899 
Kalsbeek, A., Voorn, P., Buijs, R. M., Pool, C. W., and Uylings, H. B. (1988). Development of the dopaminergic innervation in the prefrontal cortex of the rat. J. Comp. Neurol. 269, 58-72. doi: 10.1002/cne.902690105

Karam, C. S., Ballon, J. S., Bivens, N. M., Freyberg, Z., Girgis, R. R., LizardiOrtiz, J. E., etal. (2010). Signaling pathways in schizophrenia: emerging targets and therapeutic strategies. Trends Pharmacol. Sci. 31, 381-390. doi: 10.1016/j.tips.2010.05.004

Karege, F., Meary, A., Perroud, N., Jamain, S., Leboyer, M., Ballmann, E., et al. (2012). Genetic overlap between schizophrenia and bipolar disorder: a study with AKT1 gene variants and clinical phenotypes. Schizophr. Res. 135, 8-14. doi: 10.1016/j.schres.2011.12.015

Kaufmann, W. E., and Moser, H. W. (2000). Dendritic anomalies in disorders associated with mental retardation. Cereb. Cortex 10, 981-991. doi: $10.1093 /$ cercor/10.10.981

Kellendonk, C., Simpson, E. H., Polan, H. J., Malleret, G., Vronskaya, S., Winiger, V., et al. (2006). Transient and selective overexpression of dopamine D2 receptors in the striatum causes persistent abnormalities in prefrontal cortex functioning. Neuron 49, 603-615. doi: 10.1016/j.neuron.2006.01.023

Kern, C. H., Stanwood, G. D., and Smith, D. R. (2010). Preweaning manganese exposure causes hyperactivity, disinhibition, and spatial learning and memory deficits associated with altered dopamine receptor and transporter levels. Synapse 64, 363-378. doi: 10.1002/syn.20736

Kim, Y., Wang, W. Z., Comte, I., Pastrana, E., Tran, P. B., Brown, J., et al. (2010). Dopamine stimulation of postnatal murine subventricular zone neurogenesis via the D3 receptor. J. Neurochem. 114, 750-760. doi: 10.1111/j.14714159.2010.06799.x

Krasnova, I. N., Betts, E. S., Dada, A., Jefferson, A., Ladenheim, B., Becker, K. G., et al. (2007). Neonatal dopamine depletion induces changes in morphogenesis and gene expression in the developing cortex. Neurotox. Res. 11, 107-130. doi: 10.1007/BF03033390

Langen, M., Leemans, A., Johnston, P., Ecker, C., Daly, E., Murphy, C. M., et al. (2012). Front-striatal circuitry and inhibitory control in autism: findings from diffusion tensor imaging tractography. Cortex 48, 183-193. doi: 10.1016/j.cortex.2011.05.018

Lao, C. L., Lu, C. S., and Chen, J. C. (2013). Dopamine D(3) receptor activation promotes neural stem/progenitor cell proliferation through AKT and ERK1/2 pathways and expands type-B and -C cells in adult subventricular zone. Glia 61, 475-489. doi: 10.1002/glia.22449

Le Moine, C., and Bloch, B. (1995). D1 and D2 dopamine receptor gene expression in the rat striatum: sensitive cRNA probes demonstrate prominent segregation of D1 and D2 mRNAs in distinct neuronal populations of the dorsal and ventral striatum. J. Comp. Neurol. 355, 418-426. doi: 10.1002/cne.903550308

Le Moine, C., and Gaspar, P. (1998). Subpopulations of cortical GABAergic interneurons differ by their expression of D1 and D2 dopamine receptor subtypes. Mol. Brain Res. 58, 231-236. doi: 10.1016/S0169-328X(98)00118-1

Lee, F. J., Xue, S., Pei, L., Vukusic, B., Chery, N., Wang, Y., et al. (2002). Dual regulation of NMDA receptor functions by direct protein-protein interactions with the dopamine D1 receptor. Cell 111, 219-230. doi: 10.1016/S0092-8674(02)00962-5

Leppanen, J. M. (2006). Emotional information processing in mood disorders: a review of behavioral and neuroimaging findings. Curr. Opin. Psychiatry 19, 34-39. doi: 10.1097/01.yco.0000191500.46411.00

Letinic, K., Zoncu, R., and Rakic, P. (2002). Origin of GABAergic neurons in the human neocortex. Nature 417, 645-649. doi: 10.1038/nature00779

Lewis, D. A., and Levitt, P. (2002). Schizophrenia as a disorder of neurodevelopment. Annu. Rev. Neurosci. 25, 409-432. doi: 10.1146/annurev.neuro.25.112701.142754

Lewis, P. D., Patel, A. J., Bendek, G., and Balazs, R. (1977). Effect of reserpine on cell proliferation in the developing rat brain: a quantivative histological study. Brain Res. 129, 299-308. doi: 10.1016/0006-8993(77)90009-9

Li, F., Ohtani, A., Senzaki, K., and Shiga, T. (2013). Receptor-dependent regulation of dendrite formation of noradrenaline and dopamine in non-gabaergic cerebral cortical neurons. Dev. Neurobiol. 73, 370-383. doi: 10.1002/dneu. 22065

Li, X., Rosborough, K. M., Friedman, A. B., Zhu, W., and Roth, K. A. (2007). Regulation of mouse brain glycogen synthase kinase- 3 by atypical antipsychotics. Int. J. Neuropsychopharmacol. 10, 7-19. doi: 10.1017/s1461145706006547

Lipton, S. A., Frosch, M. P., Phillips, M. D., Tauck, D. L., and Aizenman, E. (1988). Nicotinic antagonists enhance process outgrowth by rat retinal ganglion cells in culture. Science 239, 1293-1296. doi: 10.1126/science.3344435
Liu, J., Lester, B. M., Neyzi, N., Sheinkopf, S. J., Gracia, L., Kekatpure, M., et al. (2013). Regional brain morphometry and impulsivity in adolescents following prenatal exposure to cocaine and tobacco. JAMA Pediatr. 167, 348-354. doi: 10.1001/jamapediatrics.2013.550

Liu, W. S., Pesold, C., Rodriguez, M. A., Carboni, G., Auta, J., Lacor, P., et al. (2001). Down-regulation of dendritic spine and glutamic acid decarboxylase 67 expressions in the reelin haploinsufficient heterozygous reeler mouse. Proc. Natl. Acad. Sci. U.S.A. 98, 3477-3482. doi: 10.1073/pnas.051614698

Logue, S. F., Grauer, S. M., Paulsen, J., Graf, R., Taylor, N., Sung, M. A., et al. (2009). The orphan GPCR, GPR88, modulates function of the striatal dopamine system: a possible therapeutic target for psychiatric disorders? Mol. Cell. Neurosci. 42, 438-447. doi: 10.1016/j.mcn.2009.09.007

Lotto, B., Upton, L., Price, D. J., and Gaspar, P. (1999). Serotonin receptor activation enhances neurite outgrowth of thalamic neurones in rodents. Neurosci. Lett. 269, 87-90. doi: 10.1016/S0304-3940(99)00422-X

Lovestone, S., Killick, R., Di Forti, M., and Murray, R. (2007). Schizophrenia as a GSK-3 dysregulation disorder. Trends Neurosci. 30, 142-149. doi: 10.1016/j.tins.2007.02.002

Lu, H., Lim, B., and Poo, M.-M. (2009). Cocaine exposure in utero alters synaptic plasticity in the medial prefrontal cortex of postnatal rats. J. Neurosci. 29, 12664 12674. doi: 10.1523/JNEUROSCI.1984-09.2009

Ma, T., Wang, C., Wang, L., Zhou, X., Tian, M., Zhang, Q., et al. (2013). Subcortical origins of human and monkey neocortical interneurons. Nat. Neurosci. 16, 15881597. doi: $10.1038 / \mathrm{nn} .3536$

Marley, A., Choy, R. W., and Von Zastrow, M. (2013). GPR88 reveals a discrete function of primary cilia as selective insulators of GPCR cross-talk. PLoS ONE 8:e70857. doi: 10.1371/journal.pone.0070857

McAllister, A. K. (2000). Cellular and molecular mechanisms of dendrite growth. Cereb. Cortex 10, 963-973. doi: 10.1093/cercor/10.10.963

McCarthy, D., Lueras, P., and Bhide, P. G. (2007). Elevated dopamine levels during gestation produce region-specific decreases in neurogenesis and subtle deficits in neuronal numbers. Brain Res. 1182, 11-25. doi: 10.1016/j.brainres.2007.08.088

McCarthy, D. M., Zhang, X., Darnell, S. B., Sangrey, G. R., Yanagawa, Y., Sadri-Vakili, G., et al. (2011). Cocaine alters BDNF expression and neuronal migration in the embryonic mouse forebrain. J. Neurosci. 31, 13400-13411. doi: 10.1523/JNEUROSCI.2944-11.2011

McGlashan, T. H., and Hoffman, R. E. (2000). SChizophrenia as a disorder of developmentally reduced synaptic connectivity. Arch. Gen. Psychiatry 57, 637648. doi: 10.1001/archpsyc.57.7.637

Meador-Woodruff, J. H., Damask, S. P., Wang, J., Haroutunian, V., Davis, K. L., and Watson, S. J. (1996). Dopamine receptor mRNA expression in human striatum and neocortex. Neuropsychopharmacology 15, 17-29. doi: $10.1016 / 0893-133 \times(95) 00150-c$

Medalia, A., and Lim, R. (2004). Treatment of cognitive dysfunction in psychiatric disorders. J. Psychiatr. Pract. 10, 17-25. doi: 10.1097/00131746-200401000-00003

Millar, J. K., Christie, S., Anderson, S., Lawson, D., Hsiao-Wei Loh, D., Devon, R. S., et al. (2001). Genomic structure and localisation within a linkage hotspot of Disrupted In Schizophrenia 1, a gene disrupted by a translocation segregating with schizophrenia. Mol. Psychiatry 6, 173-178. doi: 10.1038/sj.mp.4000784

Missale, C., Nash, S. R., Robinson, S. W., Jaber, M., and Caron, M. G. (1998). Dopamine receptors: from structure to function. Physiol. Rev. 78, 189-225.

Muly, E. C., 3rd, Szigeti, K., and Goldman-Rakic, P. S. (1998). D1 receptor in interneurons of macaque prefrontal cortex: distribution and subcellular localization. J. Neurosci. 18, 10553-10565.

Murphy, B. L., Arnsten, A. F., Goldman-Rakic, P. S., and Roth, R. H. (1996). Increased dopamine turnover in the prefrontal cortex impairs spatial working memory performance in rats and monkeys. Proc. Natl. Acad. Sci. U.S.A. 93, 1325-1329.

Nai, Q., Li, S., Wang, S. H., Liu, J., Lee, F. J., Frankland, P. W., et al. (2010). Uncoupling the D1-N-methyl-D-aspartate (NMDA) receptor complex promotes NMDA-dependent long-term potentiation and working memory. Biol. Psychiatry 67, 246-254. doi: 10.1016/j.biopsych.2009.08.011

Nair, V. D., and Mishra, R. K. (1995). Ontogenic development of dopamine D4 receptor in rat brain. Brain Res. Dev. Brain Res. 90, 180-183. doi: 10.1016/01653806(96)83499-7

Navarro, G., Moreno, E., Bonaventura, J., Brugarolas, M., Farre, D., Aguinaga, D., et al. (2013). Cocaine inhibits dopamine D2 receptor signaling via sigma1-D2 receptor heteromers. PLOS ONE 8:e61245. doi: 10.1371/journal.pone. 0061245 
Neely, M. D., Schmidt, D. E., and Deutch, A. Y. (2007). Cortical regulation of dopamine depletion-induced dendritic spine loss in striatal medium spiny neurons. Neuroscience 149, 457-464. doi: 10.1016/j.neuroscience.2007. 06.044

Neisewander, J. L., Lucki, I., and Mcgonigle, P. (1991). Neurochemical changes associated with the persistence of spontaneous oral dyskinesia in rats following chronic reserpine treatment. Brain Res. 558, 27-35. doi: 10.1016/00068993(91)90710-D

Niwa, M., Kamiya, A., Murai, R., Kubo, K., Gruber, A. J., Tomita, K., et al. (2010). Knockdown of DISC1 by in utero gene transfer disturbs postnatal dopaminergic maturation in the frontal cortex and leads to adult behavioral deficits. Neuron 65 , 480-489. doi: 10.1016/j.neuron.2010.01.019

Nohesara, S., Ghadirivasfi, M., Mostafavi, S., Eskandari, M. R., Ahmadkhaniha, H., Thiagalingam, S., et al. (2011). DNA hypomethylation of MB-COMT promoter in the DNA derived from saliva in schizophrenia and bipolar disorder. J. Psychiatr. Res. 45, 1432-1438. doi: 10.1016/j.jpsychires.2011.06.013

O'Brien, M. S., and Anthony, J. C. (2005). Risk of becoming cocaine dependent: epidemiological estimates for the United States, 2000-2001. Neuropsychopharmacology 30, 1006-1018. doi: 10.1038/sj.npp.1300681

Ohtani, N., Goto, T., Waeber, C., and Bhide, P. G. (2003). Dopamine modulates cell cycle in the lateral ganglionic eminence. J. Neurosci. 23, 2840-2850.

Okubo, Y., Suhara, T., Suzuki, K., Kobayashi, K., Inoue, O., Terasaki, O., et al. (1997). Decreased prefrontal dopamine D1 receptors in schizophrenia revealed by PET. Nature 385, 634-636. doi: 10.1038/385634a0

Olson, L., Boréus, L. O., and Seiger, Å. (1973). Histochemical demonstration and mapping of 5-hydroxytryptamine- and catecholamine-containing neuron systems in the human fetal brain. Z. Anat. Entwicklungsgesch. 139, 259-282. doi: 10.1007/bf00519968

Onténiente, B., König, N., Sievers, J., Jenner, S., Klemm, H. P., and Marty, R. (1980). Structural and biochemical changes in rat cerebral cortex after neonatal 6-hydroxydopamine administration. Anat. Embryol. 159, 245-255. doi: $10.1007 /$ bf00317649

Padmanabhan, A., and Luna, B. (2013). Developmental imaging genetics: linking dopamine function to adolescent behavior. Brain Cogn. doi: 10.1016/j.bandc.2013.09.011

Parker, D., Ferreri, K., Nakajima, T., Lamorte, V. J., Evans, R., Koerber, S. C., et al. (1996). Phosphorylation of CREB at Ser-133 induces complex formation with CREB-binding protein via a direct mechanism. Mol. Cell. Biol. 16, 694-703.

Patel, A. J., Bendek, G., Balazs, R., and Lewis, P. D. (1977). Effect of reserpine on cell proliferation in the developing rat bran: a biochemical study. Brain Res. 129, 283-297. doi: 10.1016/0006-8993(77)90008-7

Penzes, P., Cahill, M. E., Jones, K. A., Vanleeuwen, J. E., and Woolfrey, K. M. (2011). Dendritic spine pathology in neuropsychiatric disorders. Nat. Neurosci. 14, 285-293. doi: 10.1038/nn.2741

Persico, A. M., Di Pino, G., and Levitt, P. (2006). Multiple receptors mediate the trophic effects of serotonin on ventroposterior thalamic neurons in vitro. Brain Res. 1095, 17-25. doi: 10.1016/j.brainres.2006.04.006

Petanjek, Z., Kostovic, I., and Esclapez, M. (2009). Primate-specific origins and migration of cortical GABAergic neurons. Front. Neuroanat. 3:26. doi: 10.3389/neuro.05.026.2009

Piazza, P. V., Rougé-Pont, F., Deminière, J. M., Kharoubi, M., Le Moal, M., and Simon, H. (1991). Dopaminergic activity is reduced in the prefrontal cortex and increased in the nucleus accumbens of rats predisposed to develop amphetamine self-administration. Brain Res. 567, 169-174. doi: 10.1016/0006-8993(91) 91452-7

Pino, G. D., Moessner, R., Lesch, K., Lauder, J., and Persico, A. (2004). Roles for serotonin in neurodevelopment: more than just neural transmission. Curr. Neuropharmacol. 2, 403-417. doi: 10.2174/1570159043359495

Popolo, M., Mccarthy, D. M., and Bhide, P. G. (2004). Influence of dopamine on precursor cell proliferation and differentiation in the embryonic mouse telencephalon. Dev. Neurosci. 26, 229-244. doi: 10.1159/000082140

Prestoz, L., Jaber, M., and Gaillard, A. (2012). Dopaminergic axon guidance: which makes what? Front. Cell. Neurosci. 6:32. doi: 10.3389/fncel.2012.00032

Pugh, P. C., and Berg, D. K. (1994). Neuronal acetylcholine receptors that bind alpha-bungarotoxin mediate neurite retraction in a calcium-dependent manner. J. Neurosci. 14, 889-896.

Radhu, N., De Jesus, D. R., Ravindran, L. N., Zanjani, A., Fitzgerald, P. B., and Daskalakis, Z. J. (2013). A meta-analysis of cortical inhibition and excitability using transcranial magnetic stimulation in psychiatric disorders. Clin. Neurophysiol. 124, 1309-1320. doi: 10.1016/j.clinph.2013.01.014

Rapoport, J. L., Giedd, J. N., and Gogtay, N. (2012). Neurodevelopmental model of schizophrenia: update 2012. Mol. Psychiatry 17, 1228-1238. doi: 10.1038/mp.2012.23

Reinoso, B. S., Undie, A. S., and Levitt, P. (1996). Dopamine receptors mediate differential morphological effects on cerebral cortical neurons in vitro. J. Neurosci. Res. 43, 439-453. doi: 10.1002/(SICI)1097-4547(19960215)43:4<439::AIDJNR5 $>3.0 . \mathrm{CO} ; 2-\mathrm{G}$

Roeper, J. (2013). Dissecting the diversity of midbrain dopamine neurons. Trends Neurosci. 36, 336-342. doi: 10.1016/j.tins.2013.03.003

Rosenberg, D. R., and Lewis, D. A. (1995). Postnatal maturation of the dopaminergic innervation of monkey prefrontal and motor cortices: a tyrosine hydroxylase immunohistochemical analysis. J. Comp. Neurol. 358, 383-400. doi: 10.1002/cne.903580306

Roussotte, F., Soderberg, L., Warner, T., Narr, K., Lebel, C., Behnke, M., et al. (2012). Adolescents with prenatal cocaine exposure show subtle alterations in striatal surface morphology and frontal cortical volumes. J. Neurodev. Disord. 4, 22. doi: 10.1186/1866-1955-4-22

Ruediger, T., and Bolz, J. (2007). Neurotransmitters and the development of neuronal circuits. Adv. Exp. Med. Biol. 621, 104-115. doi: 10.1007/978-0-38776715-4_8

Sanchez, C., Diaz-Nido, J., and Avila, J. (2000). Phosphorylation of microtubuleassociated protein 2 (MAP2) and its relevance for the regulation of the neuronal cytoskeleton function. Progr. Neurobiol. 61, 133-168. doi: 10.1016/S03010082(99)00046-5

Santana, N., Mengod, G., and Artigas, F. (2009). Quantitative analysis of the expression of dopamine D1 and D2 receptors in pyramidal and GABAergic neurons of the rat prefrontal cortex. Cereb. Cortex 19, 849-860. doi: 10.1093/cercor/ bhn 134

Schambra, U. B., Duncan, G. E., Breese, G. R., Fornaretto, M. G., Caron, M. G., and Fremeau, R. T. Jr. (1994). Ontogeny of D1A and D2 dopamine receptor subtypes in rat brain using in situ hybridization and receptor binding. Neuroscience 62, 65-85. doi: 10.1016/0306-4522(94)90315-8

Schmidt, U., Beyer, C., Oestreicher, A. B., Reisert, I., Schilling, K., and Pilgrim, C. (1996). Activation of dopaminergic D1 receptors promotes morphogenesis of developing striatal neurons. Neuroscience 74, 453-460. doi: 10.1016/03064522(96)00201-1

Schmidt, U., Pilgrim, C., and Beyer, C. (1998). Differentiative effects of dopamine on striatal neurons involve stimulation of the cAMP/PKA pathway. Mol. Cell. Neurosci. 11, 9-18. doi: 10.1006/mcne.1998.0668

Selemon, L. D., and Friedman, H. R. (2013). Motor stereotypies and cognitive perseveration in non-human primates exposed to early gestational irradiation. Neuroscience 248C, 213-224. doi: 10.1016/j.neuroscience.2013.06.006

Seshadri, S., Zeledon, M., and Sawa, A. (2013). Synapse-specific contributions in the cortical pathology of schizophrenia. Neurobiol. Dis. 53, 26-35. doi: 10.1016/j.nbd.2013.01.009

Shah, P. J., Ogilvie, A. D., Goodwin, G. M., and Ebmeier, K. P. (1997). Clinical and psychometric correlates of dopamine D2 binding in depression. Psychol. Med. 27, 1247-1256. doi: 10.1017/S0033291797005382

Sharp, S. I., Mcquillin, A., and Gurling, H. M. (2009). Genetics of attentiondeficit hyperactivity disorder (ADHD). Neuropharmacology 57, 590-600. doi: 10.1016/j.neuropharm.2009.08.011

Sheaff, R., and Roberts, J. (1998). Regulation of G1 phase. Results Probl. Cell Differ. 22, 1-34. doi: 10.1007/978-3-540-69686-5_1

Shen, J., Zhang, L., Song, W. L., Meng, T., Wang, X., Chen, L., et al. (2013). Design, synthesis and biological evaluation of bivalent ligands against A1-D1 receptor heteromers. Acta Pharma. Sin. 34, 441-452. doi: 10.1038/aps.2012.151

Sherren, N., and Pappas, B. A. (2005). Selective acetylcholine and dopamine lesions in neonatal rats produce distinct patterns of cortical dendritic atrophy in adulthood. Neuroscience 136, 445-456. doi: 10.1016/j.neuroscience.2005. 08.053

Shuen, J. A., Chen, M., Gloss, B., and Calakos, N. (2008). Drdla-tdTomato BAC transgenic mice for simultaneous visualization of medium spiny neurons in the direct and indirect pathways of the basal ganglia. J. Neurosci. 28, 2681-2685. doi: 10.1523/jneurosci.5492-07.2008

Sigala, S., Zoli, M., Palazzolo, F., Faccoli, S., Zanardi, A., Mercuri, N. B., etal. (2007). Selective disarrangement of the rostral telencephalic 
cholinergic system in heterozygous reeler mice. Neuroscience 144, 834-844. doi: 10.1016/j.neuroscience.2006.10.013

Sillivan, S. E. (2011). Dopamine Receptor Stimulation Regulates Expression of Developmental Genes and Disrupts Netrin-1-Mediated Axon Guidance. Ph.D thesis, Vanderbilt University, Nashville.

Sillivan, S. E., and Konradi, C. (2011). Expression and function of dopamine receptors in the developing medial frontal cortex and striatum of the rat. Neuroscience 199, 501-514.

Simpson, E. H., Kellendonk, C., and Kandel, E. (2010). A possible role for the striatum in the pathogenesis of the cognitive symptoms of schizophrenia. Neuron 65, 585-596. doi: 10.1016/j.neuron.2010.02.014

Small, D. H., Reed, G., Whitefield, B., and Nurcombe, V. (1995). Cholinergic regulation of neurite outgrowth from isolated chick sympathetic neurons in culture. J. Neurosci. 15, 144-151.

Smiley, J. F., Williams, S. M., Szigeti, K., and Goldman-Rakic, P. S. (1992). Light and electron microscopic characterization of dopamine-immunoreactive axons in human cerebral cortex. J. Comp. Neurol. 321, 325-335. doi: $10.1002 /$ cne. 903210302

Song, Z. M., Undie, A. S., Koh, P. O., Fang, Y. Y., Zhang, L., Dracheva, S., et al. (2002). D1 dopamine receptor regulation of microtubule-associated protein-2 phosphorylation in developing cerebral cortical neurons. J. Neurosci. 22, 60926105.

Spencer, G. E., Klumperman, J., and Syed, N. I. (1998). Neurotransmitters and neurodevelopment. Role of dopamine in neurite outgrowth, target selection and specific synapse formation. Perspect. Dev. Neurobiol. 5, 451-467.

Speranza, L., Chambery, A., Di Domenico, M., Crispino, M., Severino, V., Volpicelli, F., et al. (2013). The serotonin receptor 7 promotes neurite outgrowth via ERK and Cdk5 signaling pathways. Neuropharmacology 67, 155-167. doi: 10.1016/j.neuropharm.2012.10.026

Spronsen, M., and Hoogenraad, C. (2010). Synapse pathology in psychiatric and neurologic disease. Curr. Neurol. Neurosci. Rep. 10, 207-214. doi: 10.1007/s11910010-0104-108

Staal, W. G., De Krom, M., and De Jonge, M. V. (2012). Brief report: the dopamine-3-receptor gene (DRD3) is associated with specific repetitive behavior in autism spectrum disorder (ASD). J. Autism Dev. Disord. 42, 885-888. doi: $10.1007 / \mathrm{s} 10803-011-1312-\mathrm{z}$

Stanwood, G., and Levitt, P. (2001). "The effects of cocaine on the developing nervous system," Handbook of Developmental Cognitive Neuroscience, eds C. A. Nelson and M. Luciana (Cambridge: MIT Press), 519-536.

Stanwood, G. D., and Levitt, P. (2007). Prenatal exposure to cocaine produces unique developmental and long-term adaptive changes in dopamine D1 receptor activity and subcellular distribution. J. Neurosci. 27, 152-157. doi: 10.1523/JNEUROSCI.4591-06.2007

Stanwood, G. D., Parlaman, J. P., and Levitt, P. (2005). Anatomical abnormalities in dopaminoceptive regions of the cerebral cortex of dopamine D1 receptor mutant mice. J. Comp. Neurol. 487, 270-282. doi: 10.1002/cne.20548

Stanwood, G. D., Washington, R. A., and Levitt, P. (2001a). Identification of a sensitive period of prenatal cocaine exposure that alters the development of the anterior cingulate cortex. Cereb. Cortex 11, 430-440. doi: 10.1093/cercor/11. 5.430

Stanwood, G. D., Washington, R. A., Shumsky, J. S., and Levitt, P. (2001b). Prenatal cocaine exposure produces consistent developmental alterations in dopaminerich regions of the cerebral cortex. Neuroscience 106, 5-14. doi: 10.1016/S03064522(01)00256-1

Südhof, T. (2006). "Synaptogenesis: when long-distance relations become intimate," in Molecular Mechanisms of Synaptogenesis, eds A. Dityatev and A. El-Husseini (USA: Springer), 1-9.

Sugahara, M., and Shiraishi, H. (1998). Synaptic density of the prefrontal cortex regulated by dopamine instead of serotonin in rats. Brain Res. 814, 143-156. doi: 10.1016/S0006-8993(98)01068-3

Surmeier, D. J., Carrillo-Reid, L., and Bargas, J. (2011). Dopaminergic modulation of striatal neurons, circuits, and assemblies. Neuroscience 198, 3-18. doi: 10.1016/j.neuroscience.2011.08.051

Tajiri, M., Hayata-Takano, A., Seiriki, K., Ogata, K., Hazama, K., Shintani, N., et al. (2012). Serotonin 5-HT(7) receptor blockade reverses behavioral abnormalities in PACAP-deficient mice and receptor activation promotes neurite extension in primary embryonic hippocampal neurons: therapeutic implications for psychiatric disorders. J. Mol. Neurosci. 48, 473-481. doi: 10.1007/s12031-012-9861-y
Tennyson, V. M., Budininkas-Schoenebeck, M., and Gershon, P. (1982). Effects of chronic reserpine treatment on development of maturity of the putamen in fetal rabbits. Brain Res. Bull. 9, 651-662. doi: 10.1016/0361-9230(82)90169-1

Thiselton, D. L., Vladimirov, V. I., Kuo, P. H., Mcclay, J., Wormley, B., Fanous, A., et al. (2008). AKT1 is associated with schizophrenia across multiple symptom dimensions in the Irish study of high density schizophrenia families. Biol. Psychiatry 63, 449-457. doi: 10.1016/j.biopsych.2007.06.005

Thompson, B., Levitt, P., and Stanwood, G. (2009). Prenatal exposure to drugs: effects on brain development and implications for policy and education. Nat. Rev. Neurosci. 10, 303-312. doi: 10.1038/nrn2598

Todd, R. D. (1992). Neural development is regulated by classical neurotransmitters: dopamine D2 receptor stimulation enhances neurite outgrowth. Biol. Psychiatry 31, 794-807. doi: 10.1016/0006-3223(92)90311-M

Trakhtenberg, E. F., and Goldberg, J. L. (2012). The role of serotonin in axon and dendrite growth. Int. Rev. Neurobiol. 106, 105-126. doi: 10.1016/b978-0-12407178-0.00005-3

Tritsch, N. X., and Sabatini, B. L. (2012). Dopaminergic modulation of synaptic transmission in cortex and striatum. Neuron 76, 33-50. doi: 10.1016/j.neuron.2012.09.023

Trowbridge, S., Narboux-Neme, N., and Gaspar, P. (2011). Genetic models of serotonin (5-HT) depletion: what do they tell us about the developmental role of 5-HT? Anat. Rec. (Hoboken) 294, 1615-1623. doi: 10.1002/ar.21248.

van Kesteren, R. E., and Spencer, G. E. (2003). The role of neurotransmitters in neurite outgrowth and synapse formation. Rev. Neurosci. 14, 217-231. doi: 10.1515/REVNEURO.2003.14.3.217

Van Waes, V., Tseng, K. Y., and Steiner, H. (2011). GPR88 - a putative signaling molecule predominantly expressed in the striatum: cellular localization and developmental regulation. Basal Ganglia 1, 83-89. doi: 10.1016/j.baga.2011.04.001

Verney, C., Berger, B., Adrien, J., Vigny, A., and Gay, M. (1982). Development of the dopaminergic innervation of the rat cerebral cortex. A light microscopic immunocytochemical study using anti-tyrosine hydroxylase antibodies. Brain Res. 281, 41-52.

Verney, C., Milosevic, A., Alvarez, C., and Berger, B. (1993). Immunocytochemical evidence of well-developed dopaminergic and noradrenergic innervations in the frontal cerebral cortex of human fetuses at midgestation. J. Comp. Neurol. 336, 331-344. doi: 10.1002/cne.903360303

Verney, C., Zecevic, N., Nikolic, B., Alvarez, C., and Berger, B. (1991). Early evidence of catecholaminergic cell groups in 5- and 6-week-old human embryos using tyrosine hydroxylase and dopamine- $\beta$-hydroxylase immunocytochemistry. Neurosci. Lett. 131, 121-124. doi: 10.1016/0304-3940(91) 90351-S

Villalba, R. M., Lee, H., and Smith, Y. (2009). Dopaminergic denervation and spine loss in the striatum of MPTP-treated monkeys. Exp. Neurol. 215, 220-227. doi: 10.1016/j.expneurol.2008.09.025

Volkow, N. D., Gur, R. C., Wang, G. J., Fowler, J. S., Moberg, P. J., Ding, Y. S., et al. (1998). Association between decline in brain dopamine activity with age and cognitive and motor impairment in healthy individuals. Am. J. Psychiatry 155, 344-349.

Voorn, P., Kalsbeek, A., Jorritsma-Byham, B., and Groenewegen, H. J. (1988). The pre- and postnatal development of the dopaminergic cell groups in the ventral mesencephalon and the dopaminergic innervation of the striatum of the rat. Neuroscience 25, 857-887. doi: 10.1016/0306-4522(88)90041-3

Wang, H. D., and Deutch, A. Y. (2008). Dopamine depletion of the prefrontal cortex induces dendritic spine loss: reversal by atypical antipsychotic drug treatment. Neuropsychopharmacology 33, 1276-1286. doi: 10.1038/sj.npp.1301521

Wang, H. D., Stanwood, G. D., Grandy, D. K., and Deutch, A. Y. (2009). Dystrophic dendrites in prefrontal cortical pyramidal cells of dopamine D1 and D2 but not D4 receptor knockout mice. Brain Res. 1300, 58-64. doi: 10.1016/j.brainres.2009.09.008

Whitford, K. L., Dijkhuizen, P., Polleux, F., and Ghosh, A. (2002). Molecular control of cortical dendrite development. Annu. Rev. Neurosci. 25, 127-149. doi: 10.1146/annurev.neuro.25.112701.142932

Wonders, C. P., and Anderson, S. A. (2006). The origin and specification of cortical interneurons. Nat. Rev. Neurosci. 7, 687-696. doi: 10.1038/nrn1954

Workman, A. D., Charvet, C. J., Clancy, B., Darlington, R. B., and Finlay, B. L. (2013). Modeling transformations of neurodevelopmental sequences across mammalian species. J. Neurosci. 33, 7368-7383. doi: 10.1523/jneurosci.5746-12. 2013 
Yokofujita, J., Oda, S., Igarashi, H., Sato, F., and Kuroda, M. (2008). Synaptic characteristics between cortical cells in the rat prefrontal cortex and axon terminals from the ventral tegmental area that utilize different neurotransmitters. Int. J. Neurosci. 118, 1443-1459. doi: 10.1080/00207450701870253

Yuste, R., and Bonhoeffer, T. (2001). Morphological changes in dendritic spines associated with long-term synaptic plasticity. Annu. Rev. Neurosci. 24, 1071-1089. doi: 10.1146/annurev.neuro.24.1.1071

Yuste, R., and Bonhoeffer, T. (2004). Genesis of dendritic spines: insights from ultrastructural and imaging studies. Nat. Rev. Neurosci. 5, 24-34. doi: $10.1038 / \mathrm{nrn} 1300$

Zecevic, N., and Verney, C. (1995). Development of the catecholamine neurons in human embryos and fetuses, with special emphasis on the innervaton of the cerebral cortex. J. Comp. Neurol. 351, 509-535. doi: 10.1002/cne.903510404

Zhang, L., Bai, J., Undie, A. S., Bergson, C., and Lidow, M. S. (2005). D1 dopamine receptor regulation of the levels of the cell-cycle-controlling proteins, cyclin D, P27 and Raf-1, in cerebral cortical precursor cells is mediated through cAMPindependent pathways. Cereb. Cortex 15, 74-84. doi: 10.1093/cercor/bhh110

Zhang, W., and Benson, D. L. (2000). Development and molecular organization of dendritic spines and their synapses. Hippocampus 10, 512-526. doi: 10.1002/1098-1063(2000)10:5<512::AID-HIPO2>3.0.CO;2-M

Zhang, X., Bearer, E. L., Boulat, B., Hall, F. S., Uhl, G. R., and Jacobs, R. E. (2010). Altered neurocircuitry in the dopamine transporter knockout mouse brain. PLoS ONE 5:e11506. doi: 10.1371/journal.pone.0011506
Zuckerman, L., Rehavi, M., Nachman, R., and Weiner, I. (2003). Immune activation during pregnancy in rats leads to a postpubertal emergence of disrupted latent inhibition, dopaminergic hyperfunction, and altered limbic morphology in the offspring: a novel neurodevelopmental model of schizophrenia. Neuropsychopharmacology 28, 1778-1789. doi: 10.1038/sj.npp. 1300248

Conflict of Interest Statement: The authors declare that the research was conducted in the absence of any commercial or financial relationships that could be construed as a potential conflict of interest.

Received: 28 October 2013; accepted: 01 December 2013; published online: 19 December 2013.

Citation: Money KM and Stanwood GD (2013) Developmental origins of brain disorders: roles for dopamine. Front. Cell. Neurosci. 7:260. doi: 10.3389/fncel.2013.00260 This article was submitted to the journal Frontiers in Cellular Neuroscience.

Copyright (c) 2013 Money and Stanwood. This is an open-access article distributed under the terms of the Creative Commons Attribution License (CC BY). The use, distribution or reproduction in other forums is permitted, provided the original author(s) or licensor are credited and that the original publication in this journal is cited, in accordance with accepted academic practice. No use, distribution or reproduction is permitted which does not comply with these terms. 